\title{
Greenhouse gas emissions from riparian zone cropland in a tributary bay of the Three Gorges Reservoir, China
}

\author{
XiaoXiao Wang ${ }^{\text {Corresp., } 1,2}$, Ping Huang ${ }^{1}$, Maohua Ma ${ }^{1}$, Kun Shan $^{1}$, Zhaofei Wen ${ }^{1}$, Shengjun Wu ${ }^{\text {Corresp. } 1}$ \\ ${ }^{1}$ Key Laboratory of Reservoir Aquatic Environment, Chongqing Institute of Green and Intelligent Technology, Chinese Academy of Sciences, ChongQing, \\ China \\ University of Chinese Academy of Sciences, Beijing, China \\ Corresponding Authors: XiaoXiao Wang, Shengjun Wu \\ Email address: wangxiaoxiao@cigit.ac.cn,wsj@cigit.ac.cn
}

Background. A huge reservoir was formed by the Three Gorges Dam in China, which also formed a riparian zone along the bank of the reservoir. In the period of low water-level, the riparian zone in tributary bays of the Three Gorges Reservoir (TGR) was always unordered cultivated, owing to its gentle slope and high soil fertility. This land-use practice creates high potential of generating greenhouse gas (GHG) emissions with periodic water level fluctuation.

Methods. To evaluate potential GHG emissions from the soil-air interface, the static opaque chamber method was adopted to evaluate the effect of elevations (180 m, $175 \mathrm{~m}, 170 \mathrm{~m}$ and $165 \mathrm{~m}$ ) and land use types (dry lands, paddy fields and grass fields) from April to September in 2015 and 2016.

Results. The results showed that carbon dioxide $\left(\mathrm{CO}_{2}\right)$ was the main contributor of GHG emission in riparian zone most likely because of high organic carbon from residues. Furthermore, high soil water content in paddy fields resulted in significantly higher methane $\left(\mathrm{CH}_{4}\right)$ flux than that in dry lands and grass fields. Compared to grass fields, anthropogenic activities in croplands were attributed with a decrease of soil total carbon and GHG emissions. However, i nundation duration of different elevations was found to have no significant effect on $\mathrm{CH}_{4}$ and $\mathrm{CO}_{2}$ emissions in the riparian zone, and the mean nitrous oxide $\left(\mathrm{N}_{2} \mathrm{O}\right)$ flux from dry lands at an elevation of $165 \mathrm{~m}$ was significantly higher than that of other elevations likely because of tillage and manure application. The high $\mathrm{N}_{2} \mathrm{O}$ fluxes produced from tillage and fertilizer suggested that, in order to potentially mitigate GHG emissions from the riparian zone, more attention must be paid to the farming practices in dry lands at low elevations (below $165 \mathrm{~m}$ ) in the riparian zone. Understanding factors that contribute to GHG emissions will help guide ecological restoration of riparian zones in the TGR. 


\section{Greenhouse gas emissions from riparian zone}

2 cropland in a tributary bay of the Three Gorges

3 Reservoir, China

4

5

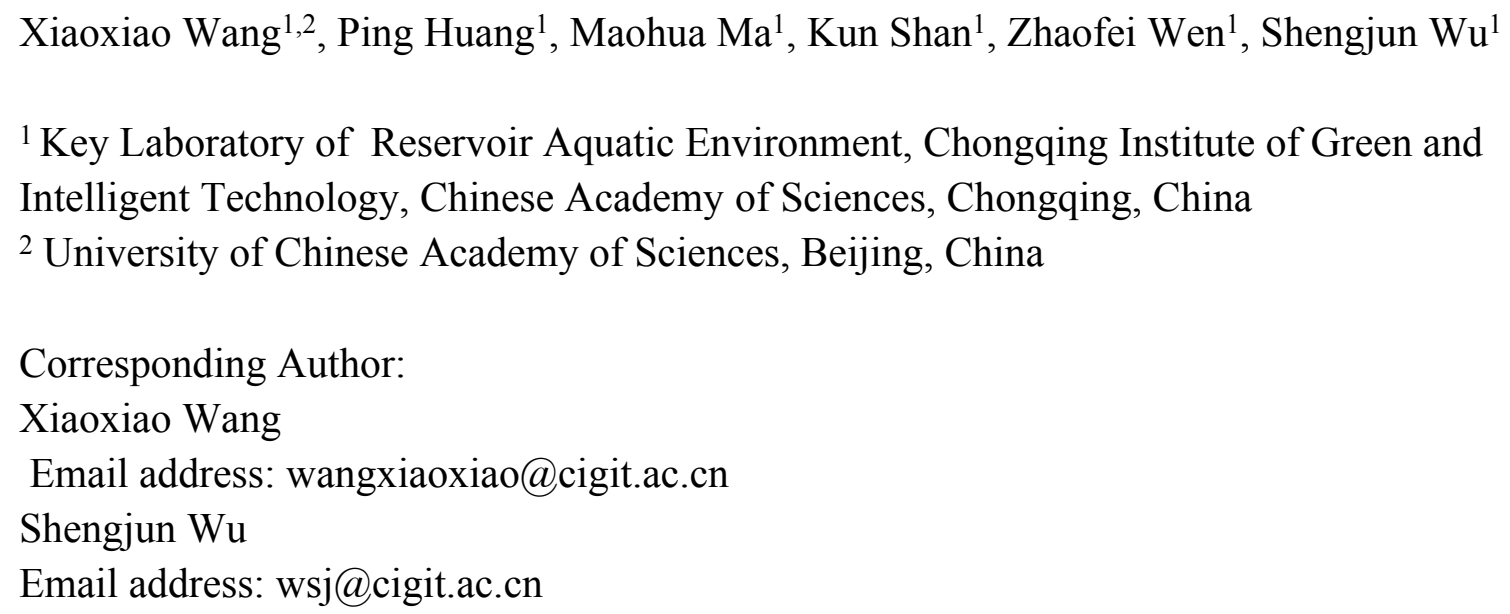

\section{Abstract}

Background. A huge reservoir was formed by the Three Gorges Dam in China, which also formed a riparian zone along the bank of the reservoir. In the period of low water-level, the riparian zone in tributary bays of the Three Gorges Reservoir (TGR) was always unordered cultivated, owing to its gentle slope and high soil fertility. This land-use practice creates high potential of generating greenhouse gas (GHG) emissions with periodic water level fluctuation.

Methods. To evaluate potential GHG emissions from the soil-air interface, the static opaque chamber method was adopted to evaluate the effect of elevations $(180 \mathrm{~m}, 175 \mathrm{~m}, 170 \mathrm{~m}$ and 165 $\mathrm{m}$ ) and land use types (dry lands, paddy fields and grass fields) from April to September in 2015 and 2016.

Results. The results showed that carbon dioxide $\left(\mathrm{CO}_{2}\right)$ was the main contributor of GHG emission in riparian zone most likely because of high organic carbon from residues. Furthermore, high soil water content in paddy fields resulted in significantly higher methane $\left(\mathrm{CH}_{4}\right)$ flux than that in dry lands and grass fields. Compared to grass fields, anthropogenic activities in croplands were attributed with a decrease of soil total carbon and GHG emissions. However, inundation duration of different elevations was found to have no significant effect on $\mathrm{CH}_{4}$ and $\mathrm{CO}_{2}$ emissions in the riparian zone, and the mean nitrous oxide $\left(\mathrm{N}_{2} \mathrm{O}\right)$ flux from dry lands at an elevation of $165 \mathrm{~m}$ was significantly higher than that of other elevations likely because of tillage and manure application. The high $\mathrm{N}_{2} \mathrm{O}$ fluxes produced from tillage and fertilizer suggested that, in order to potentially mitigate GHG emissions from the riparian zone, more attention must be paid to the farming practices in dry lands at low elevations (below 165m) in the riparian zone. Understanding factors 
39 that contribute to GHG emissions will help guide ecological restoration of riparian zones in the 40 TGR.

\section{Introduction}

42 The report from the Intergovernmental Panel on Climate Change (IPCC) pointed out that carbon gases (GHGs) and can remain ten to hundreds of years (or even more) in the atmosphere. Although the research on GHG emissions from reservoirs started in the 1990s (Kelly et al., 1993), extralarge reservoir ecosystems have been less studied in China. Around the world, such studies have mostly focused on a permanent flooded area, rather than the riparian zone (Chen et al., 2014; Duchemin et al., 1995; Huttunen et al., 2003; Kelly et al., 1994).

As the ecotone area of substance and energy exchange between aquatic and terrestrial ecosystems, the riparian zone is regarded as a hot region of GHG emissions, although the area is relatively smaller than reservoirs (Gilliam, 1994; Kankaala et al., 2004; Naimanand and Décamps, 1997). At present, theories for marsh wetland and paddy fields, as well as lakes and rivers, are usually applied in order to understand the GHG emissions and their mechanisms of riparian zones (Demarty and Bastien, 2011). Compared with natural wetlands and paddy fields, the riparian zones of reservoirs are characterized with high and unorderly fluxes owing to frequent water level fluctuations. First, dry-wet alternation events can disintegrate the soil aggregates, changing the soil porosity to release the nutrients (Park et al., 2007). Second, the decomposed plant residues, which resulted in soil organic matter accumulation after submergence (Lima, 2008), may increase $\mathrm{CO}_{2}$ and $\mathrm{CH}_{4}$ emission. Third, cultivation as a typical anthropogenic activity in the riparian zone not only changes soil structure, but also alters processes of nutrients cycling (Kasimirklemedtsson et al., 2010). Agricultural GHG emissions have been estimated as $11 \%$ of China's national emissions i.e., $820 \mathrm{Mt} \mathrm{CO}_{2}$-equivilent, whereas emissions from rice cultivation were $374 \mathrm{Mt} \mathrm{CO}_{2}$-equivilent (National Coordination Committee on Climate Change, 2012). Most of the research on GHG emissions in cropland focus on the field of permanent reclamation, while studies on intermittent reclamation in the riparian zones with periodic water level fluctuation are lacking.

The Three Gorges Dam, regarded as the biggest hydro-power project in the world, has been operating at full capacity since the end of 2010. Since then, a large area of land has been submerged into reservoir water. The water level of Three Gorges Reservoir (TGR) fluctuated from the elevation of $145 \mathrm{~m}$ to $175 \mathrm{~m}$ (Fig. 1). A total of $632 \mathrm{~km}^{2}$ of land were submerged due to the dam construction, and approximately $33.1 \%$ of total inundated area was farm land in Chongqing (Xu et al., 2013). Bay ecosystem is the typical zone in TGR, and is directly influenced by anthropogenic activities and water level fluctuation, because of its low slope, large area and high density of population nearby (Cheng, 2017). Most of the GHG emission studies on the TGR in recent years focused on the air-water interface for eutrophication, ignoring the soil-air interface in the riparian zone (Chen et al., 2011; Tao et al., 2012). The riparian zone as a newly created marsh was in the transition stage from terrestrial ecosystem to wetland ecosystem, and became an important source of $\mathrm{CH}_{4}, \mathrm{CO}_{2}$ and $\mathrm{N}_{2} \mathrm{O}$ emissions, owing to the intense biogeochemistry (Fisher et al., 2014; Vidon et al., 2016). Farming practice was found to play an important role in $\mathrm{CH}_{4}$ and $\mathrm{N}_{2} \mathrm{O}$ emissions 
during various water levels in the TGR, after normal impoundment in 2010 (Yang et al., 2012; Chen, 2011). As the number of fluctuation periods increased, the quantity and quality of soil organic matter in agricultural ecosystems would change in the riparian zone (Demarty and Bastien, 2011), potentially leading to a change of the GHG emissions.

In summary, the study of $\mathrm{CO}_{2}, \mathrm{CH}_{4}$ and $\mathrm{N}_{2} \mathrm{O}$ emissions in cropland of the riparian zone in the TGR addresses a data gap of GHG emissions influenced by both anthropogenic activities and water level fluctuation. This study was motivated by two research questions: 1) Is cultivation, as the typical human activity in the bay riparian zone, a key factor in producing the GHG emission after several fluctuation periods? 2) How do cultivation and water level fluctuation jointly influence cropland emission in the riparian zone? To answer questions, three aims were set up as follows: 1) comparing flux differences of $\mathrm{CO}_{2}, \mathrm{CH}_{4}$ and $\mathrm{N}_{2} \mathrm{O}$ in different elevations in riparian cropland; 2) comparing flux differences of $\mathrm{CO}_{2}, \mathrm{CH}_{4}$ and $\mathrm{N}_{2} \mathrm{O}$ among dry lands, paddy fields and grasslands in the riparian zone during the growing season; 3) evaluating the Global Warming Potential of the cropland in the riparian zone.

\section{Materials \& Methods}

\section{General description of farm land and experimental design}

The study area was located at the Wuyang Bay $\left(31^{\circ} 11^{\prime} 20^{\prime \prime} \mathrm{N}, 108^{\circ} 27^{\prime} 40^{\prime \prime} \mathrm{E}\right)$ in the Yetang Creek of the Pengxi river basin in the TGR (Fig. 2A). The total area is ca. $2.44 \times 10^{5} \mathrm{~m}^{2}$, with a mean annual air temperature of $18.2^{\circ} \mathrm{C}$ (Chen et al., 2014). According to hydrologic records, the water level of this area rises to $175 \mathrm{~m}$ at the end of October (the reservoir charging at peak level) and drops to $155 \mathrm{~m}$ at early April as the reservoir discharges. Thus, agricultural activities in this area are carried out between April to August. In this study, an area from $165 \mathrm{~m}$ to $180 \mathrm{~m}$ during the crop growing season was chosen to analyze GHG emissions.

According to field surveys in 2015, a total of 25 households with a population of 106 were recorded, and the main income source is agricultural production in Wuyang Bay. The soil type of this area is yellow soil (soil taxonomy), and the basic physic-chemical properties of experimental soil are shown in Table 1. Main crops in the study area are corn in dry lands and rice in paddy fields, and some vegetables at an elevation of 165m (Fig. 2B and C). Some abandoned croplands were not used for several years, and have gradually become grass fields. Fertilizers were manually applied immediately after corn planting, and additional fertilizers were applied to paddy fields in March. Amounts of the fertilizers were about $1500 \mathrm{~kg} \cdot \mathrm{hm}^{-2} \cdot \mathrm{a}^{-1}$ of urea and $1500 \mathrm{~kg} \cdot \mathrm{hm}-2 \cdot \mathrm{a}^{-1}$ of compound fertilizer in corn fields, and about 1050 to $1500 \mathrm{~kg} \cdot \mathrm{hm}^{-2} \cdot \mathrm{a}^{-1}$ of urea and $1050 \mathrm{~kg} \cdot \mathrm{hm}^{-}$ $2 \cdot \mathrm{a}^{-1}$ of compound fertilizer in paddy fields. Manure was applied in vegetable fields. After crop harvest, most rice straw was cut and moved to outside fields and corn straw was left in the field.

\section{Field sampling and measurements}

Based on variations in the water levels and different land-use types, the experimental sites were chosen and classified into three groups: 1) different elevations (165-180m) of croplands; 2) different land use types of dry lands, paddy fields and grass fields; 3 ) diurnal variations in dry lands and paddy fields. 
Soil surface gas samples were collected almost monthly using the static-chamber method and a modified gas chromatograph method from April through September in 2015 and 2016. The closed static chamber $(\varphi 30.5 \mathrm{~cm})$ (Fig. 3) was an opaque PVC material that was mounted on a PVC base frame in each plot, which had been inserted into the soil to a $10 \mathrm{~cm}$ depth. To make the covers gastight, water was poured into the grooves of the frame before each gas sampling. Each sampling site in every elevation was represented by one static chamber in dry land and one in paddy field in 2015. Three replicate static chambers were set up in dry lands, paddy fields and grass fields separately at the elevation of $170 \mathrm{~m}$ in 2016 for land use analyses. In each plot, GHG flux were made at the row position between plants in croplands, and aboveground vegetation in each plot of grasslands was cut off before gas sampling. Sampling time was selected from 9 a.m. to 11 a.m., when transient emissions represent the mean emission of the day ( $\mathrm{Li}$ et al., 2016). Gas samples were collected from each chamber at 0,10,20 and 30 min after the chamber was deployed using a polypropylene medical syringe through a triple valve.

Sampling to assess diurnal variations of GHG emissions was conducted in May, July and September. May and July represent the growing season and September represents the harvest season. One sampling site in dry land and paddy field at $170 \mathrm{~m}$ was chosen to measure the diurnal GHG emissions. Gas samples were collected every $2 \mathrm{~h}$ from 8:00 of the first day to 6:00 of the subsequent day in Beijing standard time.

The concentration of $\mathrm{N}_{2} \mathrm{O}, \mathrm{CH}_{4}$ and $\mathrm{CO}_{2}$ in gas samples were determined by gas chromatography (Agilent 7890B). $\mathrm{CO}_{2}$ and $\mathrm{CH}_{4}$ were detected with a hydrogen flame ionization detector (FID). $\mathrm{N}_{2} \mathrm{O}$ was detected with a Porapak Q packed column (80/100 mesh) and electroncapture detector $(\mathrm{ECD})$ with a $63 \mathrm{Ni}$. The temperature of the detector was $300^{\circ} \mathrm{C}$. Fluxes of $\mathrm{N}_{2} \mathrm{O}$, $\mathrm{CH}_{4}$ and $\mathrm{CO}_{2}$ were calculated as by the algorithm follows (Flessa et al., 1995):

$$
F=\rho * \frac{V}{A} * \frac{P}{P_{0}} * \frac{273}{273+T} * \frac{d c}{d t}
$$

Where $\rho\left(\mathrm{kg} \cdot \mathrm{m}^{-3}\right)$ is the concentration of GHG in standard atmospheric condition; $\mathrm{V}\left(\mathrm{m}^{3}\right)$ is the air volume in the chamber; $A\left(\mathrm{~m}^{2}\right)$ is the soil surface area in the chamber; $P(\mathrm{~Pa})$ is atmospheric pressure; $T\left({ }^{\circ} \mathrm{C}\right)$ is the air temperature in the chamber; dc/dt is concentration changes of GHGs in chamber per unit time $\left(\mathrm{ppm} \cdot \mathrm{h}^{-1}\right) . F$ is the flux of GHGs $\left(\mathrm{mg} \cdot \mathrm{m}^{-2} \cdot \mathrm{h}^{-1}\right)$.

Total daily flux (TDF) was calculated using the following formula (Xu et al., 2017):

$$
T D F=\left(\sum_{\mathrm{i}=1}^{\mathrm{n}=12} F_{i}\right) \times 2
$$

Where $i$ is the measuring time and $F_{i}$ means the flux at different times of the day. Cumulative emission of GHG (CE) was calculated as follows:

$$
C E=\sum_{i=1}^{n}\left(\frac{F_{i}+F_{i+1}}{2}\right) *\left(t_{i+1}-t_{i}\right) * 24 / 100
$$

Where $C E$ is the cumulative fluxes of GHG $\left(\mathrm{kg} \cdot \mathrm{hm}^{-1}\right) ; F$ is the flux of GHG; $i$ is the number of sampling events; $t$ is the day of the sampling events; $n$ is the total number of sampling events. Cumulative fluxes of GHG in paddy fields and dry lands were calculated from April to September in 2015 and 2016. 
155

156

157

158

159

160

161

162

163

164

165

166

167

168

169

170

171

172

173

174

175

176

177

178

179

180

181

182

183

184

185

186

187

188

189

190

191

192

193

During each gas sampling event, soil volumetric water content (VWC) and soil temperature (ST) $(10 \mathrm{~cm}$ depth) were measured within a radius of $30 \mathrm{~cm}$ from the sampling chamber using a portable moisture meter (HH2) and thermometer in soil. Soil gravimetric water content (GWC), nitrate nitrogen $\left(\mathrm{NO}_{3}{ }^{-}-\mathrm{N}\right)$, ammonia nitrogen $\left(\mathrm{NH}_{4}{ }^{+}-\mathrm{N}\right)$, total carbon (TC), total nitrogen (TN) and dissolved organic carbon (DOC) were measured for the topsoil $(0-15 \mathrm{~cm})$ within a radius of $30 \mathrm{~cm}$ from the sampling chamber. Soil samples were taken to the lab and stored at $4{ }^{\circ} \mathrm{C}$ for the physicochemical analysis. $\mathrm{NO}_{3}{ }^{-}-\mathrm{N}$ and $\mathrm{NH}_{4}{ }^{+}-\mathrm{N}$ were measured by a flow injection analyzer (FIA star 5000); TC and TN were measured with an elemental analyzer (VarioEL cube). PH was measured after shaking with water for 30min (Ye et al., 2017); Soil organic matter was measured by LOI550 (Zhou et al. 2014); Soil GWC was determined using the drying method $\left(105^{\circ} \mathrm{C}\right.$ for 12h), and bulk density was determined in the gravimetric method (Avnimelech et al., 2001). Dissolved organic carbon was measured through colorimetric analysis (Yang $\mathrm{N}$ et al., 2016).

\section{Statistical analysis}

The Global Warming Potential (GWP) was developed to reflect the global warming impacts of different gases. To reflect the total GHG emissions, the $\mathrm{CH}_{4}$ and $\mathrm{N}_{2} \mathrm{O}$ fluxes were converted to a $\mathrm{CO}_{2}$-equivalent with unit $\mathrm{mg}-\mathrm{CO}_{2} \mathrm{~m}^{-2} \cdot \mathrm{h}^{-1}\left(C_{\mathrm{N}_{2} \mathrm{O}}\right.$ and $C E_{C H_{4}}$, respectively), using a GWP of 28 for $\mathrm{CH}_{4}$ and 265 for $\mathrm{N}_{2} \mathrm{O}$ over 100 years (IPCC, 2013).

$$
\mathrm{GWP}_{\text {soil export }}=\mathrm{CE}_{\mathrm{CO}_{2}}+\mathrm{CE}_{\mathrm{CH}_{4}} \times 28+\mathrm{CE}_{\mathrm{N}_{2} \mathrm{O}} \times 265
$$

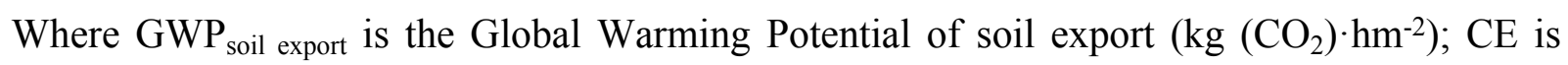
accumulative emission flux of GHG.

All datasets were processed with Origin 20.0 software for figure construction. One-Way ANOVA was implemented in the software of SPASS 22.0 to compare the significant differences in GHG fluxes and soil environmental parameters from different elevations and land-use sites. To ensure that residuals from different statistical analyses were normally distributed and homogeneous, variables were $\log$ transformed. As an alternative, Kruskal-Wallis $\mathrm{H}$ test was used to deal with those with non-normal distributions $\left(\mathrm{CH}_{4}\right.$ fluxes and $\mathrm{N}_{2} \mathrm{O}$ fluxes in different land uses). A value of $P<0.05$ was used to infer statistical significance.

The type of ordination method appropriate for GHG emissions across a gradient length was determined through detrended correspondence analysis (DCA) (Borcard et al., 1992). Because gradient length was smaller than 4 in this study, redundancy analysis (RDA) was chosen to analyze the relationships between GHG metrics and environmental parameters. All explanatory variables and GHG metrics were standardized with the function: $\left(\mathrm{y}_{i}-\mathrm{y}_{\min }\right) /\left(\mathrm{y}_{\max }-\mathrm{y}_{\min }\right)$. RDA was performed using the R package "vegan", and validated by Monte Carlo methods with 999 permutations (Shan et al., 2019).

\section{Results}

\section{GHG fluxes from different elevations during the growing season}

During the discharging period, $\mathrm{CH}_{4}$ fluxes from dry lands at four elevations ranged from -0.48 to $2.44 \mathrm{mg} \cdot \mathrm{m}^{-2} \cdot \mathrm{h}^{-1}$ (Fig. 4A). $\mathrm{CH}_{4}$ fluxes from paddy fields at three elevations in 2015 ranged from -0.87 to $10.13 \mathrm{mg} \cdot \mathrm{m}^{-2} \cdot \mathrm{h}^{-1}$ between April to September (Fig. 4B). 
194

195

196

197

198

199

200

201

202

203

204

205

206

207

208

209

210

211

212

213

214

215

216

217

218

219

220

221

222

223

224

225

226

227

228

229

230

231

232

No significant differences in $\mathrm{CH}_{4}$ and $\mathrm{CO}_{2}$ emissions from different elevations were found (Table 2). However, $\mathrm{CO}_{2}$ emissions in dry lands and paddy fields varied in different elevations during growing season (Fig. $4 \mathrm{C}$ and D). Mean $\mathrm{CO}_{2}$ fluxes from dry lands were estimated as $358.75 \pm 139.78 \mathrm{mg} \cdot \mathrm{m}^{-2} \cdot \mathrm{h}^{-1}$ (mean \pm standard error) $(180 \mathrm{~m}), 231.95 \pm 189.22 \mathrm{mg} \cdot \mathrm{m}^{-2} \cdot \mathrm{h}^{-1}(175 \mathrm{~m})$, $342.91 \pm 196.22 \mathrm{mg} \cdot \mathrm{m}^{-2} \cdot \mathrm{h}^{-1}(170 \mathrm{~m})$ and $328.31 \pm 100.73 \mathrm{mg} \cdot \mathrm{m}^{-2} \cdot \mathrm{h}^{-1}(165 \mathrm{~m})$. Meanwhile, mean $\mathrm{CO}_{2}$ fluxes from paddy fields were measured as $161.36 \pm 272.79 \mathrm{mg} \cdot \mathrm{m}^{-2} \cdot \mathrm{h}^{-1} \quad(175 \mathrm{~m})$, $183.68 \pm 293.36 \mathrm{mg} \cdot \mathrm{m}^{-2} \cdot \mathrm{h}^{-1}(170 \mathrm{~m})$ and $311.85 \pm 539.82 \mathrm{mg} \cdot \mathrm{m}^{-2} \cdot \mathrm{h}^{-1}(165 \mathrm{~m})$. A decreasing trend was showed along with the rising elevation in paddy fields.

$\mathrm{N}_{2} \mathrm{O}$ fluxes varied from -39.92 to $1594.14 \mu \mathrm{g} \cdot \mathrm{m}^{-2} \cdot \mathrm{h}^{-1}$, and the highest $\mathrm{N}_{2} \mathrm{O}$ flux was from dry lands at the elevation of $165 \mathrm{~m}$ in June (Fig. 4E). The mean $\mathrm{N}_{2} \mathrm{O}$ fluxes from dry lands at an elevation of $165 \mathrm{~m}\left(627.04 \pm 721.16 \mu \mathrm{g} \cdot \mathrm{m}^{-2} \cdot \mathrm{h}^{-1}\right)$ were significantly higher $(F=4.809, P=0.008)$ than those at an elevation of $180 \mathrm{~m}\left(44.73 \pm 71.51 \mu \mathrm{g} \cdot \mathrm{m}^{-2} \cdot \mathrm{h}^{-1}\right), 175 \mathrm{~m}\left(59.82 \pm 148.26 \mu \mathrm{g} \cdot \mathrm{m}^{-2} \cdot \mathrm{h}^{-1}\right)$ and 170 $\mathrm{m}\left(22.67 \pm 15.56 \mu \mathrm{g} \cdot \mathrm{m}^{-2} \cdot \mathrm{h}^{-1}\right)$ (Table 2). Mean $\mathrm{N}_{2} \mathrm{O}$ fluxes at different elevations in paddy fields ranged from 2.88 to $20.03 \mu \mathrm{g} \cdot \mathrm{m}^{-2} \cdot \mathrm{h}^{-1}$, but the means were associated with very high variability (Fig.4F). Therefore, there might be visible trends in the overall means, but they exhibited a very weak or no statistical difference in $\mathrm{N}_{2} \mathrm{O}$ flux at different sampling elevations. Concretely, the mean of $\mathrm{N}_{2} \mathrm{O}$ flux at an elevation of $175 \mathrm{~m}\left(20.03 \pm 22.41 \mu \mathrm{g} \cdot \mathrm{m}^{-2} \cdot \mathrm{h}^{-1}\right)$ in paddy fields tended to be higher than those values at $170 \mathrm{~m}\left(9.52 \pm 25.77 \mu \mathrm{g} \cdot \mathrm{m}^{-2} \cdot \mathrm{h}^{-1}\right)$ and $165 \mathrm{~m}\left(2.88 \pm 16.45 \mu \mathrm{g} \cdot \mathrm{m}^{-2} \cdot \mathrm{h}^{-1}\right)$.

\section{GHG flux from different land use types}

From April to September in 2016, the mean $\mathrm{CH}_{4}$ fluxes from paddy fields $\left(0.35 \pm 0.72 \mathrm{mg} \cdot \mathrm{m}^{-2} \cdot \mathrm{h}^{-}\right.$ 1) tended to be higher than those from the dry lands $\left(0.036 \pm 0.09 \mathrm{mg} \cdot \mathrm{m}^{-2} \cdot \mathrm{h}^{-1}\right)$ and grasslands $\left(0.08 \pm 0.20 \mathrm{mg} \cdot \mathrm{m}^{-2} \cdot \mathrm{h}^{-1}\right)$ (Table 3, Fig. 5A). However, there was no significant difference in $\mathrm{CH}_{4}$ fluxes of these three land uses. Monthly $\mathrm{CH}_{4}$ fluxes varied greatly among the sampling period, and the $\mathrm{CH}_{4}$ flux exhibited lowest level in August 17th. In paddy fields, the maximum $\mathrm{CH}_{4}$ flux was observed in July, and it was the source of methane throughout the sampling time.

$\mathrm{CO}_{2}$ fluxes were positive in dry lands and grasslands, but negative in paddy fields in the early growth stage (Fig. 5B). In the summer, $\mathrm{CO}_{2}$ fluxes in paddy fields increased to positive levels as the temperature rose. On August 17th, $\mathrm{CO}_{2}$ emissions in the three land use types increased. The mean $\mathrm{CO}_{2}$ fluxes from grasslands $\left(395.43 \pm 283.32 \mathrm{mg} \cdot \mathrm{m}^{-2} \cdot \mathrm{h}^{-1}\right)$ were significantly higher $(F=9.958$, $P<0.001)$ than those values from the dry lands $\left(266.91 \pm 180.79 \mathrm{mg} \cdot \mathrm{m}^{-2} \cdot \mathrm{h}^{-1}\right)$ and paddy fields $\left(151.63 \pm 213.55 \mathrm{mg} \cdot \mathrm{m}^{-2} \cdot \mathrm{h}^{-1}\right)($ Table 3$)$.

$\mathrm{N}_{2} \mathrm{O}$ fluxes were positive in these three land use types from April to September in 2016(Fig. 5C). With respect to $\mathrm{N}_{2} \mathrm{O}$ emission in different land use types, there was significant difference ( $H=19.556, P=0.005)$ between paddy fields and dry lands. Due to high variability in measured values, no significant difference was found between grass fields and paddy fields in $\mathrm{N}_{2} \mathrm{O}$ flux. However, the overall means might exhibit a distinct trend. For instance, the mean $\mathrm{N}_{2} \mathrm{O}$ fluxes from paddy fields $\left(22.36 \pm 34.89 \mu \mathrm{g} \cdot \mathrm{m}^{-2} \cdot \mathrm{h}^{-1}\right)$ was approximately two times lower than those values from dry lands $\left(50.61 \pm 40.71 \mu \mathrm{g} \cdot \mathrm{m}^{-2} \cdot \mathrm{h}^{-1}\right)$ and grasslands $\left(50.42 \pm 75.18 \mu \mathrm{g} \cdot \mathrm{m}^{-2} \cdot \mathrm{h}^{-1}\right)$ (Table 3).

Diurnal emissions of GHG emissions during the growing season 
233

234

235

236

237

238

239

240

241

242

243

244

245

246

247

248

249

250

251

252

253

254

255

256

257

258

259

260

261

262

263

264

265

266

267

268

269

270

271

272

Table 4 exhibited the diurnal emissions of GHGs during different seasons in cropland of the riparian zone. It was shown that TDF of $\mathrm{CO}_{2}$ in paddy field in September was much higher than that in other seasons, while TDF of $\mathrm{CH}_{4}$ and $\mathrm{N}_{2} \mathrm{O}$ flux in paddy field in September were much lower than that in other seasons. According to the lines of diurnal variations of GHG emissions in Fig. 6 and GHGs flux in Table 4, GHG flux from 9:00 to 11:00 basically can represented the mean emission of the day.

Diurnal changes in $\mathrm{CO}_{2}$ and $\mathrm{N}_{2} \mathrm{O}$ fluxes from dry lands and paddy fields were observed during the growing season (Fig.6). $\mathrm{CO}_{2}$ and $\mathrm{N}_{2} \mathrm{O}$ fluxes were low at night and high during the day in dry lands, and the same trajectory was observed in daily air temperature. The daily emission peaks of $\mathrm{CO}_{2}$ and $\mathrm{N}_{2} \mathrm{O}$ fluxes were all at 2-4 pm, and the amplitude (the difference between the highest and lowest values within a day) of diurnal variations of the $\mathrm{CO}_{2}$ and $\mathrm{N}_{2} \mathrm{O}$ fluxes were various in different season. Diurnal variations in $\mathrm{CH}_{4}$ emissions were not obvious both in dry lands and paddy fields in different seasons. Moreover, no obvious fluctuating regularity of the $\mathrm{N}_{2} \mathrm{O}$ diurnal emission could be observed during the observation period in paddy fields.

Mean $\mathrm{CO}_{2}$ diurnal emission values in dry lands amounted to $404.11 \pm 114.68 \mathrm{mg} \cdot \mathrm{m}^{-2} \cdot \mathrm{h}^{-1}$ in September in $2015,475.92 .11 \pm 209.88 \mathrm{mg} \cdot \mathrm{m}^{-2} \cdot \mathrm{h}^{-1}$ in May, $146.18 \pm 45.51 \mathrm{mg} \cdot \mathrm{m}^{-2} \cdot \mathrm{h}^{-1}$ in July and $291.98 \pm 255.33 \mathrm{mg} \cdot \mathrm{m}^{-2} \cdot \mathrm{h}^{-1}$ in September in 2016(Table 4). Mean $\mathrm{CO}_{2}$ diurnal emission values in paddy fields amounted to $237.78 \pm 340.43 \mathrm{mg} \cdot \mathrm{m}^{-2} \cdot \mathrm{h}^{-1}$ in September in $2015,2.35 \pm 107.78 \mathrm{mg} \cdot \mathrm{m}^{-}$ ${ }^{2} \cdot \mathrm{h}^{-1}$ in May, $50.12 \pm 46.35 \mathrm{mg} \cdot \mathrm{m}^{-2} \cdot \mathrm{h}^{-1}$ in July and $284.66 \pm 316.18 \mathrm{mg} \cdot \mathrm{m}^{-2} \cdot \mathrm{h}^{-1}$ in September in 2016. In August 2016, $\mathrm{CO}_{2}$ flux increased, the amplitude of diurnal variation was also quite high, and the peak emission were above $1000 \mathrm{mg} \cdot \mathrm{m}^{-2} \cdot \mathrm{h}^{-1}$ in dry lands and paddy fields.

Mean $\mathrm{N}_{2} \mathrm{O}$ diurnal emission values in dry lands amounted to $120.71 \pm 29.73 \mu \mathrm{g} \cdot \mathrm{m}^{-2} \cdot \mathrm{h}^{-1}$ in September 2016, which was higher than in other sampling occasions. However, there were no differences in the amplitude of diurnal variation in different seasons. Mean $\mathrm{N}_{2} \mathrm{O}$ diurnal emission values in paddy fields amounted to $-3.67 \pm 16.72$ in September 2015 and $2.24 \pm 2.05 \mu \mathrm{g} \cdot \mathrm{m}^{-2} \cdot \mathrm{h}^{-1}$ in September 2016 which was lower than that at other sampling times, and the amplitude of diurnal variation in September was also much lower than other seasons.

\section{Cumulative emission of GHG in different land use types}

Mean $\mathrm{CH}_{4}$ fluxes of the riparian zone from 2015 to 2016 in this study was $0.47 \pm 1.53 \mathrm{mg} \cdot \mathrm{m}^{-2} \cdot \mathrm{h}^{-}$ 1(Fig. 4 and Fig.5). Cumulative emission fluxes of $\mathrm{CH}_{4}$ in paddy fields were much higher than those in dry lands and grass fields (Table 5). Whereas, cumulative emission fluxes of $\mathrm{CO}_{2}$ and $\mathrm{N}_{2} \mathrm{O}$ in dry lands and grass fields were higher than those in paddy fields. GWP was $8045.46 \mathrm{~kg} \cdot \mathrm{ha}^{-1}$ in 2015 and $113392.06 \mathrm{~kg} \cdot \mathrm{ha}^{-1}$ in 2016 in paddy fields, while $14426.07 \mathrm{~kg} \cdot \mathrm{ha}^{-1}$ in 2015 and $12340.58 \mathrm{~kg} \cdot \mathrm{ha}^{-1}$ in 2016 in dry lands during the growing season. GWP in grasslands $(18322.66$ $\mathrm{kg} \cdot \mathrm{hm}^{-1}$ ) in 2016 was higher than that in cropland, which is beneficial to the high flux of $\mathrm{CO}_{2}$ $\left(17700.26 \mathrm{~kg} \cdot \mathrm{hm}^{-1}\right) . \mathrm{CO}_{2}$ emission from the sampling site contributed the most to $\mathrm{GWP}, \mathrm{CH}_{4}$ emission contributed the second most, and $\mathrm{N}_{2} \mathrm{O}$ emission contributed the least. In the whole riparian zone of the study area, $\mathrm{CO}_{2}$ emissions represented the greatest proportion of GWP $(>70.0 \%)$.

\section{Influencing factors of GHG emissions}


273

274

275

276

277

278

279

280

281

282

283

284

285

286

287

288

289

290

291

292

293

294

295

296

297

298

299

300

301

302

303

304

305

306

307

308

309

310

311

312

Air temperatures through sampling time ranged from $22.0^{\circ} \mathrm{C}$ to $40.0^{\circ} \mathrm{C}$. Soil temperature at $165 \mathrm{~m}$ of paddy fields was significantly higher $(F=6.113, P=0.003)$ than other elevations. The mean content of $\mathrm{NO}_{3}{ }^{-}-\mathrm{N}$ in soil at $165 \mathrm{~m}\left(57.66 \mathrm{mg} \cdot \mathrm{kg}^{-1}\right)$ in dry lands was significantly $(F=4.809$, $P=0.008)$ higher than that of other elevations. The mean TC $(F=5.585, P=0.004)$ and TN $(F=50.293, P=0.00)$ at $180 \mathrm{~m}$ (unflooded area) were significantly lower than others, while the TC and $\mathrm{TN}$ at $170 \mathrm{~m}$ for paddy fields were lower than others. It is clearly shown that significant variations in soil VWC exhibited an increasing trend with the increase of elevations in riparian zone. (Table 2).

Mean soil temperatures in riparian zone for dry lands, paddy fields and grass fields were $24.93^{\circ} \mathrm{C}, 26.44^{\circ} \mathrm{C}$ and $22.29^{\circ} \mathrm{C}$ through sampling time, respectively. Soil MWC in dry lands $(30.38 \%)$ was significantly $(F=9.892, P<0.001)$ lower than that in paddy fields $(49.89 \%)$ and grass fields $(39.87 \%)$, while the content of $\mathrm{NO}_{3}{ }^{-} \mathrm{N}$ in dry lands $(6.02 \mathrm{mg} \cdot \mathrm{kg}-1)$ was higher and $\mathrm{NH}_{4}{ }^{+}-\mathrm{N}$ (4.86mg $\cdot \mathrm{kg}-1$ ) was lower than that in the other two land uses. TC, TN and DOC in dry lands were lower than those in paddy fields and grasslands (Table 3).

The redundancy analysis (Fig.7) explored several potential impact factors that may regulate three types of GHG emissions based on the data obtained from all sites in the study area. Strengths of the correlations between environmental factors and the first two axes were summarized in Table 6. The first two axes accounted for $37.30 \%$ of GHGs variation in all data (2015-2016), 45.6\% in dataset from paddy fields, $53.96 \%$ in dataset from dry lands and $26.18 \%$ in dataset from grass fields. The RDA ordinations showed that the flux of $\mathrm{CO}_{2}$ positively correlated with ST, but negatively correlated with soil GWC in all data (Fig. 7A). Soil temperature and soil GWC were positively $(\mathrm{r}=0.994)$ and negatively $(\mathrm{r}=-0.998)$ correlated with the first axis, respectively. The flux of $\mathrm{N}_{2} \mathrm{O}$ positively related to $\mathrm{AT}(\mathrm{r}=0.544)$ and soil $\mathrm{NO}_{3}{ }^{-} \mathrm{N}(\mathrm{r}=0.906)$, which were positively correlated with the second axis. Soil $\mathrm{NO}_{3}{ }^{-} \mathrm{N}(\mathrm{r}=0.999)$ and $\mathrm{AT}(\mathrm{r}=0.962)$ were positively correlated with the first axis, and soil GWC was positively $(\mathrm{r}=0.952)$ correlated with the second axis in dry lands (Fig. 7B). With respect to the paddy fields, soil temperature $(\mathrm{r}=0.999)$ and air temperature $(\mathrm{r}=1.0)$ were positively correlated with the first axis. While soil $\mathrm{GWC}(\mathrm{r}=0.999)$ and $\mathrm{DOC}(\mathrm{r}=0.999)$ negatively correlated with the first axis (Fig. 7C). Increase of $\mathrm{CO}_{2}$ fluxes was stimulated by increase of soil $\mathrm{T}$ and air $\mathrm{T}$, but with the decrease of soil GWC and DOC. In grass fields, $\mathrm{CO}_{2}$ fluxes was negatively correlated with soil VWC which was positively correlated with the first axis(r=-0.896) and second axis( $\mathrm{r}=-0.444)$ (Fig. 7D).

\section{Discussion}

\section{The contribution of cultivation to GHG emissions}

This study shows that soil of the bay riparian zone acts as a weak $\mathrm{CH}_{4}$ and $\mathrm{N}_{2} \mathrm{O}$ source, but a strong $\mathrm{CO}_{2}$ source during the growing season.

Mean $\mathrm{CH}_{4}$ fluxes of the riparian zone from 2015 to 2016 in this study $\left(0.47 \pm 1.53 \mathrm{mg} \cdot \mathrm{m}^{-2} \cdot \mathrm{h}^{-1}\right)$ were similar to values reported for other wetland catchments $\left(0.0 \sim 2.22 \mathrm{mg} \cdot \mathrm{m}^{-2} \cdot \mathrm{h}^{-1}\right)$ (Badiou et al., 2011; Finocchiaro et al., 2014; Yang $\mathrm{M}$ et al., 2014). The production of $\mathrm{CH}_{4}$ in various eco-systems is closely related to the anaerobic environment, which is beneficial to the methanogen metabolic activities (Zhou, 2017; Zhang et al., 2018). Soil water content, which affects the methane 
313 consuming capacity of methane-oxidizing bacteria by changing the transmission rate and the soil 314 environmental condition (Koh et al., 2009), probably was a reason of the significant difference in 315 the $\mathrm{CH}_{4}$ fluxes among the paddy fields, dry lands and grasslands.

316 In recent years, the riparian zone is believed be an important source of $\mathrm{N}_{2} \mathrm{O}$ emissions, because 317 it might be the key area of nitrogen transformation in the whole biogeochemical system (Groffman 318 et al., 2000; Wang et al., 2006). Incomplete denitrification under anaerobic conditions was 319 considered to be the major reason for the production of $\mathrm{N}_{2} \mathrm{O}$ (Wilcock and Sorrell, 2008; Zhou et

320

321

322

323

324

325

326

327

328

329

330

331

332

333

334

335

336

337

338

339

340

341

342

343

344

345

346

347

348

349

350

351

352 al., 2014). Since $\mathrm{N}_{2} \mathrm{O}$ eventually produces $\mathrm{N}_{2}$ in anaerobic conditions, $\mathrm{N}_{2} \mathrm{O}$ emissions from paddy filed were much lower than those from dry lands and grasslands. $\mathrm{N}_{2} \mathrm{O}$ emission is limited when soil humidity completely saturates to values $>60 \%$ in paddy fields (Davidson et al., 2000; Finocchiaro et al., 2014) and nitrifiers convert ammonium into nitrates to promote the $\mathrm{N}_{2} \mathrm{O}$ flux in an aerobic soil environment after the wet soil has dried (Kaiser et al., 1996, Yang et al., 2017).Therefore, $\mathrm{N}_{2} \mathrm{O}$ fluxes in paddy fields showed a double-peak pattern before planting and after crop harvest in 2016 (Fig. 5). The $\mathrm{N}_{2} \mathrm{O}$ emission in grasslands without fertilizer might be due to surface runoff or sufficient substrate from high mineralization rates under the dry-wet alternating actions in the riparian zone (Muller et al., 2004).

Cumulative fluxes of GHGs (Table 5) showed that $\mathrm{CO}_{2}$ emission dominated the GHG fluxes when the $\mathrm{CH}_{4}$ and $\mathrm{N}_{2} \mathrm{O}$ fluxes were calculated as $\mathrm{CO}_{2}$ equivalents during the growing season, which is comparable to the results archived in Aude et al (2013) and Zhou et al (2017). Litter from soil surface, root residues and exudates in splits are the main source of soil organic matter in terrestrial ecosystems (Gleixner et al., 2005; Gonzalez-Meler et al., 2018 ). The high organic matter in riparian soil along with water level fluctuation created slow decomposition of external organic matter and microorganisms (Schimel et al., 2011), and insoluble organic carbon transferred to inorganic carbon through mineralization resulting in the increase of $\mathrm{CO}_{2}$ emissions (Andrews \&Schlesinger, 2001). Soil TC and DOC in croplands were lower than in grass fields (Table 3), probably due to the intensive interference of anthropogenic activities in cropland which may loosen the soil, increase the soil permeability, and hence lead to the easy run-off of soil DOC (Wang et al., 2005). These may also be the reasons why grass fields that grow herbaceous plants without tillage have the greatest emissions of $\mathrm{CO}_{2}$, and have the highest levels of GHG fluxes.

\section{The influence of water level fluctuation and tillage on GHG emission}

Although no significant variations in $\mathrm{CH}_{4}$ emission were found at different elevations, the mean $\mathrm{CH}_{4}$ fluxes at $180 \mathrm{~m}\left(-0.036 \mathrm{mg} \mathrm{m}^{-2} \mathrm{~h}^{-1}\right)$ (unflooded area) were lower than at other elevations (flooded area), and soil TC and TN were also lower than that at the riparian zone(Table 2), which were similar to results from Tangen (2015). However, an increasing trend did not appear as the elevation decreased in the riparian zone, which was different from the research on grasslands in TGR by Chai et al (2017). The variations in the $\mathrm{CH}_{4}$ emission in different land uses correlated with the changes in the soil water content (Fig 7), but the $\mathrm{CH}_{4}$ emission in dry lands at different elevations did not show the same decreasing trend with soil water content in riparian zone (Table 2). That means different inundation duration varied the soil water content in dry lands, but did not lead to the variations of GHG emissions, and the variations in different seasons may correlate with 
353

354

355

356

357

358

359

360

361

362

363

364

365

366

367

368

369

370

371

372

373

374

375

376

377

378

379

380

381

382

383

384

385

386

387

388

389

390

391

392

various characteristics, such as soil temperature and human interference specially, as time proceeds.

$\mathrm{N}_{2} \mathrm{O}$ fluxes in the research area showed great spatial and temporal variability. The highest $\mathrm{N}_{2} \mathrm{O}$ flux from dry lands was from the elevation of $165 \mathrm{~m}$ (May to June), which reached $1594.14 \mu \mathrm{g} \cdot \mathrm{m}^{-}$ ${ }^{2} \cdot \mathrm{h}^{-1}$ in June. $\mathrm{N}_{2} \mathrm{O}$ fluxes in dry lands showed a one-peak pattern after submergence. The flux of $\mathrm{N}_{2} \mathrm{O}$ positively related to soil $\mathrm{NO}_{3}{ }^{-}-\mathrm{N}$ (Fig. 7). In paddy fields and dry lands, $\mathrm{N}_{2} \mathrm{O}$ fluxes were positively related to air temperature and negatively related to soil TC. Application of farm manure provided the substrate for soil microbial growth, and promotes nitrification and denitrification reaction (Bouwman, 1996; Zheng et al., 2004). The major reason for the highest observed flux of $\mathrm{N}_{2} \mathrm{O}$ might be tillage and fertilization in dry lands at $165 \mathrm{~m}$ for vegetable planting in May.

Fluxes of $\mathrm{CO}_{2}$ in this study showed an insignificant increasing trend along the elevations, which was different with the study in Miyun reservoir (Yang M, 2016) and Fuling TGR (Xu, 2013). Crop harvest exposes soil at the surface. In addition, water-table position and temperature, which influences the development of aerobic and microbial activities, would influence the potential of GHGs emmission (Glatzel et al., 2004; Waddington et al., 2001). The research site went through a draught period from 10th to the 24th of August, 2016. After crop harvest, soil VWC, GWC, ST and $\mathrm{NH}_{4}^{+}-\mathrm{N}$ decreased, and $\mathrm{NO}_{3}{ }^{-}-\mathrm{N}$ increased on August 17th, 2016 (Fig. S1 and S2). Therefore, crop harvest combined with continual dry and hot weather in August increased the $\mathrm{CO}_{2}$ emission especially in paddy fields.

\section{Differences of GHG fluxes between the bay riparian zone and other zones}

GHG fluxes measured in this typical tributary bay riparian zone of the TGR were within the ranges of previous research across different sites (Table 7). Because of the higher soil moisture content, $\mathrm{CH}_{4}$ flux in paddy fields was higher than that in grass fields and dry lands in the riparian zone, but lower than that in paddy fields in Hubei and SiChuan (Lin et al., 2000; Han et al., 2005). Based on the data in Table 7 (Shiau et al., 2016; Yu et al., 2010), $\mathrm{N}_{2} \mathrm{O}$ fluxes in grass fields in riparian zone in this research were higher than in other natural wetlands due to high soil $\mathrm{NO}_{3}{ }^{-} \mathrm{N}$ and soil redox conditions, which favored mineralization in periodic water level fluctuation (Badiou et al.2011; Shiau et al., 2016). In addition, the application of nitrogen fertilizer would increase the denitrification rate and denitrification product ratio $\left(\mathrm{N}_{2} \mathrm{O} / \mathrm{N}_{2}\right)$ (Xing, 1998). So $\mathrm{N}_{2} \mathrm{O}$ fluxes in cropland system were higher than that in wetland without tillaging. Discrepancies in $\mathrm{N}_{2} \mathrm{O}$ and $\mathrm{CO}_{2}$ fluxes in different croplands are likely related to the different amount of fertilizer, as well as geographic location, weather, and timing and intensity of sampling (Stelzer et al., 2011).

GHG fluxes from this study were in line with values reported for other typical tributary bay riparian zones in TGR. $\mathrm{CH}_{4}$ emission fluxes in the natural wetland (e.g., marsh wetland) and manmade wetland (e.g., paddy fields) were higher than that from the different types of dry lands. GHG emissions in reservoirs are mainly released at the initial periods after the impoundment due to the abrupt release of nutrient substances in the flooded lands, the elevation of microbial activities, and the decomposition of unstable carbon matters, such as soils, litters, and leaves (Detmary et al., 2011). As it is in the early development of TGR riparian zone, there may be in a decreasing trend in GHG emissions in future. 
393

394

395

396

397

398

399

400

401

402

403

404

405

406

407

408

409

410

411

412

413

414

415

416

417

418

419

420

421

422

423

424

425

426

427

428

429

430

431

432

\section{Conclusions}

Riparian zones in tributary bays of the TGR are generally a source of GHGs. $\mathrm{CO}_{2}$ emission in this kind of zone mainly contributed to the GHG emissions, partly due to the high organic carbon input from the reservoir catchment, and they should be paid more attention in the future research.

Different farming practices likely changed the humidity, carbon and nitrogen of soil. GHG emissions in TGR were affected by soil temperature, soil water content and soil fertility. Riparian zone reclamation lowered $\mathrm{CO}_{2}$ emission, and increased $\mathrm{N}_{2} \mathrm{O}$ emission. Higher soil VWC led to a higher $\mathrm{CH}_{4}$ emission in paddy fields than in dry lands and grasslands. Anthropogenic activities caused a decrease of soil TC, and the decrease of GHG emission from croplands in the riparian zone. Farming was a main influence (e.g., tillage and fertilization), and caused higher $\mathrm{N}_{2} \mathrm{O}$ fluxes at $165 \mathrm{~m}$ especially. The high $\mathrm{N}_{2} \mathrm{O}$ fluxes produced from tillage and fertilizer suggest that, in order to potentially mitigate GHG emissions from the riparian zone, farming practices in dry lands at low water levels (below 165m) should be paid more attention.

Because of the resident farming activities, TGR cropland seemed to have no spatial effect along the elevation gradient. No significant difference of the amplitude of diurnal variations of GHGs in different seasons was found. However, there was a short-term increasing $\mathrm{CO}_{2}$ and decreasing $\mathrm{N}_{2} \mathrm{O}$ emission, and the diurnal variation amplitude of $\mathrm{N}_{2} \mathrm{O}$ was also much lower after draining in paddy fields. These spatial-temporal characteristics in paddy fields together with the seasonal water-level fluctuation shall be taken into account in future studies to further explore the underlying mechanisms controlling GHG emission kinetics.

\section{Acknowledgements}

We thank the farmers near the field site for assistance of sampling. Special thanks are given also due to Yi Jiang and Zhimei Liu for their help in the field and laboratory.

\section{References}

Andrews JA, Schlesinger WH. 2001. Soil $\mathrm{CO}_{2}$ dynamics, acidification, and chemical weathering in a temperate forest with experimental $\mathrm{CO}_{2}$ enrichment. Global Biogeochemical Cycles, 15(1):149-162.

Avnimelech Y, Ritvo G, Meijer LE, Kochba M. 2001. Water content, organic carbon and dry bulk density in flooded sediments. Aquacultural Engineering, 25(1):25-33.

Adviento-Borbe, MAA, Haddix ML, Binder DL, Walters DT, Dobermann A. 2010. Soil greenhouse gas fluxes and global warming potential in four high - yielding maize systems. Global Change Biology. 13(9): 1972-1988.

Amos B, Arkebauer TJ, Doran JW. 2005. Soil Surface Fluxes of Greenhouse Gases in an Irrigated Maize-Based Agroecosystem. Soil Science Society of America Journal. 69(2): 387-395.

Audet J, Elsgaard L, Kjaergaard C, Larsen SE, Hoffmann CC. 2013. Greenhouse gas emissions from a Danish riparian wetland before and after restoration. Ecological Engineering. 57(4): 170-182.

Badiou P, Mcdougal R, Dan P, Clark B. 2011. Greenhouse gas emissions and carbon sequestration potential in restored wetlands of the Canadian prairie pothole region. Wetlands Ecology \& Management. 19(3): 237-256. 
433 Borcard D, Legendre P, Drapeau P. 1992. Partialling out the spatial component of ecological $434 \quad$ variation. Ecology 73 (3): 1045-1055.

435 Bouwman, AF. 1996. Direct emission of nitrous oxide from agricultural soils. Nutrient Cycling in $436 \quad$ Agroecosystems. 46(1): 53-70.

437

438

439

Chai X, Hao Q, Huang Z, Fan Z, Jiang C. 2017. Characteristics and influencing factors of $\mathrm{CH}_{4}$ emissions from the drawdown Area of the Three Gorges reservoir. Environmental science. 38(10):4370-4379(in Chinese).

440

Cheng H, Chen C, Wu S, Zakaria AM, Liu Z. 2017.Emergy evaluation of cropping, poultry 441

442

443

444

445

446

447

448

449

450

451

452

453

454

455

456

457

458

459

460

461

462

463

464

465

466

467

468 rearing, and fish raising systems in the drawdown zone of Three Gorges Reservoir of China. Journal of Cleaner Production. 144:559-571.

Chen H, Yuan X, Chen Z, Wu Y, Liu X, Zhu D, Wu N, Zhu QA, Peng C, Li W. 2011. Methane emissions from the surface of the Three Gorges Reservoir. Journal of Geophysical Research Atmospheres. 116(D21).

Chen N, Chen Z, Wu Y, Hu A. 2014. Understanding gaseous nitrogen removal through direct measurement of dissolved $\mathrm{N}_{2}$ and $\mathrm{N}_{2} \mathrm{O}$ in a subtropical river-reservoir system. Ecological Engineering. 70(5): 56-67.

Davidson, EA, Keller M, Erickson HE, Verchot LV, Veldkamp E. 2000. Testing a Conceptual Model of Soil Emissions of Nitrous and Nitric Oxides. Bioscience. 50(8): 667-680.

Demarty M, Bastien J. 2011. GHG emissions from hydroelectric reservoirs in tropical and equatorial regions: Review of 20 years of $\mathrm{CH}$ emission measurements. Energy Policy, 39(7): 4197-4206.

Duchemin E, Lucotte M, Canuel R, Chamberland A. 1995. Production of the greenhouse gases $\mathrm{CH}_{4}$ and $\mathrm{CO}_{2}$ by hydroelectric reservoirs of the boreal region. Global Biogeochemical Cycles. 9(4): 529-540.

Fisher K, Jacinthe PA, Vidon P, Liu X, Baker ME. 2014. Nitrous oxide emission from cropland and adjacent riparian buffers in contrasting hydrogeomorphic settings. Journal of Environmental Quality, 43(1): 338-348.

Finocchiaro R, Tangen B, Gleason R. 2014. Greenhouse gas fluxes of grazed and hayed wetland catchments in the U.S. Prairie Pothole Ecoregion. Wetlands Ecology \& Management. 22(3): 305-324.

Flessa H P, Dörsch, Beese F .1995 Seasonal variation of $\mathrm{N}_{2} \mathrm{O}$ and $\mathrm{CH}_{4}$ fluxes in differently managed arable soils in southern Germany. Journal of Geophysical Research: Atmospheres, 100,(23):115-124.

Gilliam JW. 1994. Riparian Wetlands and Water Quality. Journal of Environmental Quality. 23(5): 896-900.

469

470

471 Gleixner G. 2005. 3-Stable Isotope Composition of Soil Organic Matter. Stable Isotopes \&

472

Glatzel S, Basiliko N, Moore T. 2004. Carbon dioxide and methane production potentials of peats from natural, harvested and restored sites, Eastern Québec, Canada. Wetlands, 24(2):261267. Biosphere Atmosphere Interactions. (2005): 29-46. 
473 Gonzalez-Meler MA, Poghosyan A, Leon SD, Olivera EDD, Norby R J, Struchio N C. 2018. Does 474 elevated atmospheric $\mathrm{CO}_{2}$ affect soil carbon burial and soil weathering in a forest ecosystem? 475 Peer J, 6(1):e5356.

476 Groffman PM, Gold AJ, Addy K. 2000. Nitrous oxide production in riparian zones and its 477 importance to national emission inventories. Chemosphere - Global Change Science. 2(3-4): 478 291-299.

479

480

481

482

483

484

485

486

487

488

489

490

491

492

493

494

495

496

497

498

499

500

501

502

503

504

505

506

507

508

509

510

511

512

Han GX, Zhu B, Jiang CS, Gao MR, Zhang ZJ, Ma XM.2005. Methane emission from paddy fields and its affecting factors in hills of the central Sichuan Basin. Rural Eco-Environment, 2005, 21(1):1-6

Huttunen JT., Väisänen TS, Heikkinen M, Hellsten S, Nykänen H, Nenonen O, Martikainen PJ. 2003. Corrigendum: Exchange of $\mathrm{CO}_{2}, \mathrm{CH}_{4}$ and $\mathrm{N}_{2} \mathrm{O}$ between the atmosphere and two northern boreal ponds with catchments dominated by peatlands or forests. Plant \& Soil. 256(2): 481-482.

Jiang T Guo J, Li Z, Fang F, Bai L, Li J 2012. Air-Water Surface Greenhouse Gas Flux in Pengxi River at Different Operational Stages of the Three Gorges Reservoir. Environmental Science. 33(5): 1463-1470.

Kaiser EA, Heinemeyer O. 1996. Temporal changes in $\mathrm{N}_{2} \mathrm{O}$-losses from two arable soils. Plant \& Soil. 181(1): 57-63.

Kasimirklemedtsson A, Klemedtsson L, Berglund K, Martikainen P, Silvola J, Oenema O. 2010. Greenhouse gas emissions from farmed organic soils: a review. Soil Use \& Management, 13(s4): 245-250.

Kankaala P, Ojala A, Käki T. 2004. Temporal and Spatial Variation in Methane Emissions from a Flooded Transgression Shore of a Boreal Lake. Biogeochemistry. 68(3): 297-311.

Kelly CA, Hecky RE. 1993. Are Hydroelectric Reservoirs Significant Sources of Greenhouse Gases? Ambio. 22(4): 246-248.

Kelly CA, Rudd JWM, Louis VLS, Moore T. 1994. Turning attention to reservoir surfaces, a neglected area in greenhouse studies. Eos Transactions American Geophysical Union. 75(29): 332-333.

Koh HS, Ochs CA, Yu K. W. 2009. Hydrologic gradient and vegetation controls on $\mathrm{CH}_{4}$ and $\mathrm{CO}_{2}$ fluxes in a spring-fed forested wetland. Hydrobiologia. 630(1): 271-286.

Li Z, Zhang ZY, Lin C, Chen Y, Wen A, Fang F.2016. Soil-air greenhouse gas fluxes influenced by farming practices in reservoir drawdown area: A case at the Three Gorges Reservoir in China. Journal of Environmental Management, 181: 64-73.

Lima IBT, Ramos FM., Bambace LAW, Rosa RR. 2008. Methane Emissions from Large Dams as Renewable Energy Resources: A Developing Nation Perspective. Mitigation \& Adaptation Strategies for Global Change, 13(2): 193-206.

Lin K, Xiang Y, Jiang D, Hu Q, Li Z, Du D, Tao Z. 2000.Methane Emission Flux from Paddy Fields and Its Control in Hubei.19(5):267-270(in Chinese).

Morse JL, Ardón M, Bernhardt ES. 2012. Greenhouse gas fluxes in southeastern U.S. coastal plain wetlands under contrasting land uses. Ecological Applications. 22(1): 264-280. 
513 Muller C, Stevens RJ, Laughlin RJ, Jager HJ. 2004. Microbial processes and the site of $\mathrm{N}_{2} \mathrm{O}$

514

515

516

517

518

519

520

521

522

523

524

525

526

527

528

529

530

531

532

533

534

535

536

537

538

539

540

541

542

543

544

545

546

547

548

549

550

551

552 production in a temperate grassland soil. Soil Biology \& Biochemistry. 36(3): 453-461.

Naimanand RJ, Décamps H. 1997. The Ecology of Interfaces: Riparian Zones. Annual Review of Ecology \& Systematics. 28(1): 621-658.

National Coordination Committee on Climate Change (NCCC), 2012. Second National Communication on Climate Change of the People's Republic of China. China Planning Press, Beijing (in Chinese).

Panday D, Nkongolo NV. 2015. Soil Water Potential Control of the Relationship between Moisture and Greenhouse Gas Fluxes in Corn-Soybean Field. Climate, 3: 689-696.

Park EJ, Sul WJ, Smucker AJM. 2007. Glucose additions to aggregates subjected to drying/wetting cycles promote carbon sequestration and aggregate stability. Soil Biology \& Biochemistr., 39(11):2758-2768.

Shan K, Song L, Chen W, Li L, Liu L, Wu Y, Peng L. 2019. Analysis of environmental drivers influencing interspecific variations and associations among bloom-forming cyanobacteria in large, shallow eutrophic lakes. Harmful algae, 84, 84-94.

Shiau YJ, Burchell MR, Krauss KW, Birgand F, Broome SW. 2016. Greenhouse Gas Emissions from a Created Brackish Marsh in Eastern North Carolina. Wetlands, 36(6): 1009-1024.

Stelzer RS, Bartsch LA, Richardson WB,Strauss EA. 2011. The dark side of the hyporheic zone: depth profiles of nitrogen and its processing in stream sediments. Freshwater Biology, 56(10):2021-2033.

$\mathrm{Su} \mathrm{M}$. Greenhouse gases emissions and net global warming potential in croplands as affected by different rotation systems and nitrogen management in Sichuan basin. Bei Jing: China agricultural university (in Chinese).

Tangen BA, Finocchiaro RG, Gleason RA. 2015. Effects of land use on greenhouse gas fluxes and soil properties of wetland catchments in the Prairie Pothole Region of North America. Science of the Total Environment. 533: 391-409.

Tremblay A, Varfalvy L, Roehm C, Garneau M. 2005. Greenhouse Gas Emissions-Fluxes and Processes: Hydroelectric Reservoirs and Natural Environments. Apress. 7(2): 111-127.

Vidon P, Marchese S, Welsh M, Mcmillan S. 2016. Impact of Precipitation Intensity and Riparian Geomorphic Characteristics on Greenhouse Gas Emissions at the Soil-Atmosphere Interface in a Water-Limited Riparian Zone. Water Air \& Soil Pollution, 227(1): 8.

Wang H, Wang W, Yin C, Wang Y, Lu J. 2006. Littoral zones as the "hotspots" of nitrous oxide (NO) emission in a hyper-eutrophic lake in China. Atmospheric Environment. 40(28): 55225527.

Wang Q, Wang S, Hong G, Yan L, Xiaojun YU. 2005. Influence of land use on soil organic matter. Chinese Journal of Ecology. 24(4):360-363.

Waddington JM, Rotenberg PA, Warren FJ. 2001. Peat $\mathrm{CO}_{2}$ production in a natural and cutover peatland. Biogeochemistry, 54(2):115-130.

Xing GX. 1998. $\mathrm{N}_{2} \mathrm{O}$ emission from cropland in China. Nutrient cycling in Agroecosystems. 52:249-254. 
553

554

555

556

557

558

559

560

561

562

563

564

565

566

567

568

569

570

571

572

573

574

575

576

577

578

579

580

581

582

583

584

585

586

587

Xu X, Fu G, Zou X, Ge C, Zhou Y. 2017.Diurnal variations of carbon dioxide, methane, and nitrous oxide fluxes from invasive Spartina alterniflora dominated coastal wetland in northern Jiangsu Province. Acta Oceanologica Sinica. 36(4):105-113.

Yang F, Lee X, Theng BKG, Wang B, Cheng J, Wang Q. 2017. Effect of biochar addition on short-term $\mathrm{N}_{2} \mathrm{O}$ and $\mathrm{CO}_{2}$ emissions during repeated drying and wetting of an anthropogenic alluvial soil. Environmental Geochemistry \& Health. 39(3): 1-13.

Yang L, Lu F, Wang X, Duan X, Song W, Sun B, Chen S, Zhang Q, Hou P, Zheng F. 2012. Surface methane emissions from different land use types during various water levels in three major drawdown areas of the Three Gorges Reservoir. Journal of Geophysical Research Atmospheres. 117(D10): 10109.

Yang M. Processes of greenhouse gases emission from littoral zone: case study of Miyun Reservoir. 2016. Beijing Forestry University. Beijing, China. (in Chinese).

Yang M, Geng X M, Grace J, Lu C, Zhu Y, ZhouY, Lei G C. 2014. Spatial and Seasonal $\mathrm{CH}_{4}$ Flux in the Littoral Zone of Miyun Reservoir near Beijing: The Effects of Water Level and I ts Fluctuation. Plos One. 9(4):e94275.

Yang N, Zou D, Yang M, Lin Z. 2016. Variations in Soil Microbial Biomass Carbon and Soil Dissolved Organic Carbon in the Re-Vegetation of Hilly Slopes with Purple Soil. Plos One, 11(12).

Ye F, Wu SJ, Jiang Y, den Camp HJO, Li Zhe, Zhu GB, Zheng J, Wang Y. 2016. Shifts of archaeal community structure in soil along an elevation gradient in a reservoir water level fluctuation zone. Journal of Soils and Sediments. 16: 2728-2739.

Yu J, Liu J, Sun Z, Sun W, Wang J, Wang G, Chen X. 2010. The fluxes and controlling factors of $\mathrm{N}_{2} \mathrm{O}$ and $\mathrm{CH}_{4}$ emissions from freshwater marsh in Northeast China. Science China Earth Sciences. 53(5): 700-709.

Zhang J, Xia X, Li S, Wei R. 2018. Response of methane production via propionate oxidation to carboxylated multiwalled carbon nanotubes in paddy soil enrichments. Peer J. 6(1):e4267.

Zhou L, Wang Y, Long XE, Guo J, Zhu G. 2014. High abundance and diversity of nitritedependent anaerobic methane-oxidizing bacteria in a paddy field profile. FEMS Microbiol Lett, 360:33-41.

Zheng X, Han S, Huang Y, Wang Y, Wang M. 2004. Re - quantifying the emission factors based on field measurements and estimating the direct $\mathrm{N}_{2} \mathrm{O}$ emission from Chinese croplands. Global Biogeochemical Cycles. 18(2):1-19.

Zhou S, He Y, Yuan X, Peng S, Yue J. 2017. Greenhouse gas emissions from different land-use areas in the Littoral Zone of the Three Gorges Reservoir, China. Ecological Engineering. 100: 316-324. 


\section{Table $\mathbf{1}$ (on next page)}

Physical and chemical properties of soil collected from riparian zone of Wuyang bay in 2015.

Values are means \pm standard error.

$\mathrm{n}$ : the sample size 
1

\begin{tabular}{lllllll}
\hline Land use & $\begin{array}{l}\text { Soil organic } \\
\text { matter } \\
\left(\mathrm{g} \cdot \mathrm{kg}^{-1}\right)\end{array}$ & $\begin{array}{l}\text { Bulk density } \\
\left(\mathrm{g} \cdot \mathrm{cm}^{-3}\right)\end{array}$ & $\mathrm{pH}$ & $\begin{array}{l}\text { Total } \\
\text { nitrogen } \\
\left(\mathrm{mg} \cdot \mathrm{kg}^{-1}\right)\end{array}$ & $\begin{array}{l}\mathrm{NH}_{4}^{+}-\mathrm{N} \\
\left(\mathrm{mg} \cdot \mathrm{kg}^{-1}\right)\end{array}$ & $\mathrm{NO}_{3}^{-}-\mathrm{N}$ \\
\hline $\begin{array}{l}\text { Paddy fields } \\
(\mathrm{n}=6)\end{array}$ & $17.16 \pm 4.04$ & $1.12 \pm 0.14$ & $7.14 \pm 0.27$ & $1.13 \pm 0.35$ & $17.21 \pm 17.90$ & $11.45 \pm 24.06$ \\
$\begin{array}{l}\text { Dry lands } \\
(\mathrm{n}=6)\end{array}$ & $13.36 \pm 2.29$ & $1.34 \pm 0.12$ & $7.19 \pm 0.32$ & $1.56 \pm 0.31$ & $14.39 \pm 21.12$ & $17.21 \pm 17.90$ \\
$\begin{array}{l}\text { Grass fields } \\
(\mathrm{n}=6)\end{array}$ & $16.90 \pm 3.74$ & $1.38 \pm 0.08$ & $7.12 \pm 0.24$ & $1.52 \pm 0.29$ & $6.13 \pm 4.44$ & $3.43 \pm 3.23$ \\
\hline
\end{tabular}

2 


\section{Table 2 (on next page)}

$\mathrm{CH}_{4}, \mathrm{CO}_{2}$ and $\mathrm{N}_{2} \mathrm{O}$ emissions and soil environmental parameters of different elevations in Wuyang Bay in 2015.

Values are means \pm standard error

n.a. not analyzed

a,b,c different letters in the same column means statistical significance $(P<0.05)$ 
1

\begin{tabular}{|c|c|c|c|c|c|c|c|c|c|c|c|c|}
\hline & $\begin{array}{l}\text { Elevat } \\
\text { ions }(\mathrm{m} \\
)\end{array}$ & $\begin{array}{l}\text { soil } \\
\text { volumetri } \\
\text { c water } \\
\text { content(V } \\
\text { WC) }(\%)\end{array}$ & $\begin{array}{l}\text { Soil } \\
\text { gravimetr } \\
\text { ic water } \\
\text { content(G } \\
\text { WC) (\%) }\end{array}$ & $\begin{array}{l}\text { Soil } \\
\text { temperat } \\
\text { ure } \\
\left({ }^{\circ} \mathrm{C}\right)\end{array}$ & $\begin{array}{l}\mathrm{NO}_{3}^{-}-\mathrm{N} \\
\left(\mathrm{mg} \cdot \mathrm{kg}^{-}\right. \\
\left.{ }^{1}\right)\end{array}$ & $\begin{array}{l}\mathrm{NH}_{4}^{+}-\mathrm{N} \\
\left(\mathrm{mg} \cdot \mathrm{kg}^{-1}\right)\end{array}$ & $\begin{array}{l}\text { Total } \\
\text { carbon(T } \\
\mathrm{C}) \\
\left(\mathrm{g} \cdot \mathrm{kg}^{-1}\right)\end{array}$ & $\begin{array}{l}\text { Total } \\
\text { Nitroge } \\
\mathrm{n}(\mathrm{TN}) \\
\left(\mathrm{g} \cdot \mathrm{kg}^{-1}\right)\end{array}$ & $\begin{array}{l}\text { Dissolv } \\
\text { ed } \\
\text { organic } \\
\text { carbon } \\
(\mathrm{DOC})( \\
\left.\mathrm{gkg}^{-1}\right)\end{array}$ & $\begin{array}{l}\mathrm{CH}_{4} \\
\left(\mathrm{~m}^{-2} \cdot \mathrm{h}^{-1}\right)\end{array}$ & $\begin{array}{l}\mathrm{CO}_{2} \\
\left(\mathrm{~m}^{-2} \cdot \mathrm{h}^{-1}\right)\end{array}$ & $\begin{array}{l}\mathrm{N}_{2} \mathrm{O} \\
\left(\mu \mathrm{g} \cdot \mathrm{m}^{-2} \cdot \mathrm{h}^{-}\right. \\
\left.{ }^{1}\right)\end{array}$ \\
\hline \multirow{4}{*}{$\begin{array}{l}\text { Dry } \\
\text { land } \\
\mathrm{s}\end{array}$} & 180 & $52.50 \pm 9.15^{\mathrm{a}}$ & $\begin{array}{l}25.33 \pm 4.77 \\
\text { a }\end{array}$ & $23.82 \pm 4.86^{\mathrm{a}}$ & $\begin{array}{l}16.17 \pm 18 \\
80^{\mathrm{a}}\end{array}$ & $\begin{array}{l}27.34 \pm 18 \\
80^{\mathrm{a}}\end{array}$ & $7.71 \pm 0.68^{\mathrm{a}}$ & $\begin{array}{l}0.93 \pm 0.2 \\
1^{\mathrm{a}}\end{array}$ & n.a. & $\begin{array}{l}\text { - } \\
0.036 \pm 0.21 \\
\text { a }\end{array}$ & $\begin{array}{l}358.75 \pm 139 \\
78^{\mathrm{a}}\end{array}$ & $44.73 \pm 71.51^{\mathrm{a}}$ \\
\hline & 175 & $\begin{array}{l}63.42 \pm 5.64 \\
\mathrm{~b}\end{array}$ & $\begin{array}{l}37.56 \pm 7.23 \\
b\end{array}$ & $24.84 \pm 4.32^{\mathrm{a}}$ & $\begin{array}{l}18.71 \pm 9.8 \\
1^{\text {a }}\end{array}$ & $\begin{array}{l}18.91 \pm 9.8 \\
1^{\text {a }}\end{array}$ & $\begin{array}{l}17.52 \pm 6.39 \\
\mathrm{~b}\end{array}$ & $\begin{array}{l}1.59 \pm 0.3 \\
4^{\mathrm{b}}\end{array}$ & n.a. & $0.34 \pm 0.86^{\mathrm{a}}$ & $\begin{array}{l}231.95 \pm 189 . \\
22^{\mathrm{a}}\end{array}$ & $\begin{array}{l}59.82 \pm 148.26 \\
\text { a }\end{array}$ \\
\hline & 170 & $51.40 \pm 9.53^{\mathrm{a}}$ & $\begin{array}{l}27.19 \pm 4.55 \\
\text { a }\end{array}$ & $24.5 \pm 4.15^{\mathrm{a}}$ & $\begin{array}{l}15.79 \pm 10 . \\
44^{\mathrm{a}}\end{array}$ & $\begin{array}{l}16.05 \pm 10 . \\
44^{\mathrm{a}}\end{array}$ & $\begin{array}{l}14.34 \pm 5.79 \\
\mathrm{~b}\end{array}$ & $\begin{array}{l}1.31 \pm 0.4 \\
2^{\mathrm{b}}\end{array}$ & n.a. & $\begin{array}{l}0.032 \pm 0.17 \\
\text { a }\end{array}$ & $\begin{array}{l}342.91 \pm 196 . \\
22^{\mathrm{a}}\end{array}$ & $22.68 \pm 15.56^{\mathrm{a}}$ \\
\hline & 165 & $42.56 \pm 7.78^{c}$ & $28.64 \pm 4.7^{\mathrm{c}}$ & $26.79 \pm 4.39^{\mathrm{a}}$ & $\begin{array}{l}57.56 \pm 26 . \\
98^{\mathrm{b}}\end{array}$ & $\begin{array}{l}38.23 \pm 26 \\
98^{\mathrm{a}}\end{array}$ & $\begin{array}{l}12.90 \pm 2.73 \\
\mathrm{~b}\end{array}$ & $\begin{array}{l}1.41 \pm 0.2 \\
3^{\mathrm{b}}\end{array}$ & n.a. & $0.16 \pm 0.32^{\mathrm{a}}$ & $\begin{array}{l}328.31 \pm 100 . \\
73^{\mathrm{a}}\end{array}$ & $\begin{array}{l}627.04 \pm 721.1 \\
6^{\mathrm{b}}\end{array}$ \\
\hline Padd & 175 & $\begin{array}{l}67.39 \pm 19.4 \\
1^{\text {ab }}\end{array}$ & $\begin{array}{l}64.11 \pm 20.2 \\
5^{\mathrm{a}}\end{array}$ & $25.62 \pm 2.55^{\mathrm{a}}$ & $3.29 \pm 5.56^{\mathrm{a}}$ & $\begin{array}{l}29.36 \pm 29 \\
54^{\mathrm{a}}\end{array}$ & $\begin{array}{l}19.81 \pm 3.03 \\
\text { a }\end{array}$ & $\begin{array}{l}1.88 \pm 0.2 \\
8^{\mathrm{a}}\end{array}$ & $\begin{array}{l}0.28 \pm 0.0 \\
76^{\mathrm{a}}\end{array}$ & $0.53 \pm 1.49^{\mathrm{a}}$ & $\begin{array}{l}161.36 \pm 272 . \\
79^{\mathrm{a}}\end{array}$ & $20.03 \pm 25.77^{\mathrm{a}}$ \\
\hline $\begin{array}{l}\text { y } \\
\text { field }\end{array}$ & 170 & $\begin{array}{l}67.02 \pm 20.2 \\
7^{\mathrm{a}}\end{array}$ & $\begin{array}{l}56.69 \pm 17.7 \\
8^{\mathrm{b}}\end{array}$ & $26.36 \pm 2.95^{\mathrm{ab}}$ & $2.91 \pm 6.90^{\mathrm{a}}$ & $\begin{array}{l}13.92 \pm 13 . \\
64^{\mathrm{b}}\end{array}$ & $\begin{array}{l}15.91 \pm 2.48 \\
\mathrm{~b}\end{array}$ & $\begin{array}{l}1.38 \pm 0.2 \\
8^{\mathrm{b}}\end{array}$ & $\begin{array}{l}0.22 \pm 0.0 \\
46^{\mathrm{b}}\end{array}$ & $0.19 \pm 0.55^{\mathrm{a}}$ & $\begin{array}{l}183.68 \pm 293 . \\
36^{\mathrm{a}}\end{array}$ & $9.52 \pm 35.63^{\mathrm{a}}$ \\
\hline s & 165 & $\begin{array}{l}66.26 \pm 20.5 \\
8^{b}\end{array}$ & $\begin{array}{l}59.89 \pm 20.1 \\
4^{\text {ab }}\end{array}$ & $27.80 \pm 2.54^{\mathrm{b}}$ & $0.43 \pm 0.51^{b}$ & $\begin{array}{l}20.44 \pm 19 . \\
33^{\mathrm{ab}}\end{array}$ & $\begin{array}{l}19.88 \pm 2.34 \\
\text { a }\end{array}$ & $\begin{array}{l}1.73 \pm 0.1 \\
5 \mathrm{c}\end{array}$ & $\begin{array}{l}0.22 \pm 0.0 \\
43^{\mathrm{b}}\end{array}$ & $0.96 \pm 1.89^{\mathrm{a}}$ & $\begin{array}{l}311.85 \pm 539 \\
82^{\mathrm{a}}\end{array}$ & $2.88 \pm 16.45^{\mathrm{a}}$ \\
\hline
\end{tabular}




\section{Table 3(on next page)}

$\mathrm{CH}_{4}, \mathrm{CO}_{2}$ and $\mathrm{N}_{2} \mathrm{O}$ emissions and soil environmental parameters of different land uses at the elevation of $170 \mathrm{~m}$ in Wuyang Bay in 2016.

Values are means \pm standard error

${ }^{a, b, c}$ different letters in the same column means statistical significance $(P<0.05)$ 
1

\begin{tabular}{|c|c|c|c|c|c|c|c|c|c|c|c|}
\hline $\begin{array}{l}\text { Land } \\
\text { uses }\end{array}$ & $\begin{array}{l}\text { soil } \\
\text { volumetric } \\
\text { water } \\
\text { content(V } \\
\text { WC) (\%) }\end{array}$ & $\begin{array}{l}\text { Soil } \\
\text { gravimetri } \\
\text { c water } \\
\text { content(G } \\
\text { WC) } \\
(\%)\end{array}$ & $\begin{array}{l}\text { Soil } \\
\text { temperatu } \\
\text { re }\left({ }^{\circ} \mathrm{C}\right)\end{array}$ & $\begin{array}{l}\mathrm{NO}_{3}{ }^{-}-\mathrm{N} \\
\left(\mathrm{mg} \cdot \mathrm{kg}^{-}\right. \\
\left.{ }^{1}\right)\end{array}$ & $\begin{array}{l}\mathrm{NH}_{4}^{+}-\mathrm{N} \\
\left(\mathrm{mg} \cdot \mathrm{kg}^{-1}\right)\end{array}$ & $\begin{array}{l}\text { Total } \\
\text { carbon(T } \\
\text { C) } \\
\left(\mathrm{g} \cdot \mathrm{kg}^{-1}\right)\end{array}$ & $\begin{array}{l}\text { Total } \\
\text { Nitrogen( } \\
\mathrm{TN}) \\
\left(\mathrm{g} \cdot \mathrm{kg}^{-1}\right)\end{array}$ & $\begin{array}{l}\text { Dissolve } \\
\mathrm{d} \text { organic } \\
\text { carbon } \\
(\mathrm{DOC})(\mathrm{g} \cdot \\
\left.\mathrm{kg}^{-1}\right)\end{array}$ & $\begin{array}{l}\mathrm{CH}_{4} \\
\left(\mathrm{mg} \cdot \mathrm{m}^{-2} \cdot \mathrm{h}^{-}\right. \\
\left.{ }^{1}\right)\end{array}$ & $\begin{array}{l}\mathrm{CO}_{2} \\
\left(\mathrm{mg} \cdot \mathrm{m}^{-2} \cdot \mathrm{h}^{-1}\right)\end{array}$ & $\begin{array}{l}\mathrm{N}_{2} \mathrm{O} \\
\left(\mu \mathrm{g} \cdot \mathrm{m}^{-2} \cdot \mathrm{h}^{-}\right. \\
\left.{ }^{1}\right)\end{array}$ \\
\hline $\begin{array}{l}\text { Dry } \\
\text { lands }\end{array}$ & $46.64 \pm 14.04^{\mathrm{a}}$ & $30.38 \pm 9.82^{\mathrm{a}}$ & $26.08 \pm 2.68^{\mathrm{a}}$ & $6.02 \pm 4.06^{\mathrm{a}}$ & $4.86 \pm 3.48^{\mathrm{a}}$ & $\begin{array}{l}13.52 \pm 2.24 \\
\text { a }\end{array}$ & $1.30 \pm 0.20^{\mathrm{a}}$ & $0.22 \pm 0.06^{\mathrm{a}}$ & $0.036 \pm 0.09^{\mathrm{a}}$ & $\begin{array}{l}266.91 \pm 180.7 \\
9^{\mathrm{a}}\end{array}$ & $50.61 \pm 40.71^{\mathrm{a}}$ \\
\hline $\begin{array}{l}\text { Padd } \\
\text { y } \\
\text { fields }\end{array}$ & $\begin{array}{l}60.50 \pm 23.67 \\
\mathrm{~b}\end{array}$ & $\begin{array}{l}49.89 \pm 20.42 \\
\text { b }\end{array}$ & $26.49 \pm 2.63^{\mathrm{a}}$ & $\begin{array}{l}1.74 \pm 2.44 \\
\text { b }\end{array}$ & $\begin{array}{l}16.38 \pm 18.53 \\
\text { b }\end{array}$ & $\begin{array}{l}16.01 \pm 2.70 \\
b\end{array}$ & $1.44 \pm 0.24^{\mathrm{b}}$ & $0.23 \pm 0.05^{\mathrm{a}}$ & $0.35 \pm 0.72^{\mathrm{b}}$ & $\begin{array}{l}151.63 \pm 213.5 \\
5^{\mathrm{a}}\end{array}$ & $22.36 \pm 34.89^{b}$ \\
\hline $\begin{array}{l}\text { Grass } \\
\text { fields }\end{array}$ & $49.07 \pm .71^{\mathrm{a}}$ & $39.87 \pm 64^{\mathrm{c}}$ & $26.29 \pm 3.0^{\mathrm{a}}$ & $\begin{array}{l}3.43 \pm 3.23 \\
\mathrm{~b}\end{array}$ & $6.13 \pm 4.44^{\mathrm{a}}$ & $\begin{array}{l}16.90 \pm 3.74 \\
\mathrm{~b}\end{array}$ & $1.52 \pm 0.29^{\mathrm{b}}$ & $\begin{array}{l}0.26 \pm 0.057 \\
\mathrm{~b}\end{array}$ & $0.08 \pm 0.20^{\mathrm{a}}$ & $\begin{array}{l}395.43 \pm 283.3 \\
2^{\mathrm{b}}\end{array}$ & $\begin{array}{l}50.42 \pm 75.18^{\mathrm{a}} \\
\mathrm{b}\end{array}$ \\
\hline
\end{tabular}

2 


\section{Table 4 (on next page)}

Diurnal emissions and total daily flux(TDF) of $\mathrm{GHGs}\left(\mathrm{CH}_{4}, \mathrm{CO}_{2}\right.$ and $\left.\mathrm{N}_{2} \mathrm{O}\right)$ during different seasons in cropland of Wuyang Bay.

Values are means \pm standard error 


\begin{tabular}{|c|c|c|c|c|c|}
\hline & & Sep.2015 & May 2016 & July 2016 & Sep. 2016 \\
\hline \multirow{5}{*}{ Dry lands } & Mean $\mathrm{CH}_{4} / \mathrm{mg} \cdot \mathrm{m}^{-2} \cdot \mathrm{h}^{-1}$ & $-0.015 \pm 0.11$ & $-0.018 \pm 0.071$ & $0.025 \pm 0.092$ & $0.00026 \pm 0.016$ \\
\hline & $\mathrm{CH}_{4}$ flux from $10 \mathrm{am} / \mathrm{mg} \cdot \mathrm{m}^{-2} \cdot \mathrm{h}^{-1}$ & -0.018 & 0.044 & 0.047 & 0.014 \\
\hline & Mean $\mathrm{CO}_{2} / \mathrm{mg} \cdot \mathrm{m}^{-2} \cdot \mathrm{h}^{-1}$ & $404.11 \pm 114.68$ & $475.977 \pm 209.88$ & $146.18 \pm 45.51$ & $291.98 \pm 255.34$ \\
\hline & $\mathrm{CO}_{2}$ flux from $10 \mathrm{am} / \mathrm{mg} \cdot \mathrm{m}^{-2} \cdot \mathrm{h}^{-1}$ & 316.52 & 672.90 & 163.82 & 163.95 \\
\hline & Mean $\mathrm{NO}_{2} / \mu \mathrm{g} \cdot \mathrm{m}^{-2} \cdot \mathrm{h}^{-1}$ & $52.99 \pm 18.54$ & $68.44 \pm 21.76$ & $38.34 \pm 21.31$ & $120.71 \pm 29.73$ \\
\hline \multirow{7}{*}{ Paddy field } & $\mathrm{NO}_{2}$ flux from $10 \mathrm{am} / \mathrm{mg} \cdot \mathrm{m}^{-2} \cdot \mathrm{h}^{-1}$ & 19.97 & 67.34 & 62.89 & 97.23 \\
\hline & Mean $\mathrm{CH}_{4} / \mathrm{mg} \cdot \mathrm{m}^{-2} \cdot \mathrm{h}^{-1}$ & $0.00079 \pm 0.11$ & $0.38 \pm 0.68$ & $0.061 \pm 0.12$ & $-0.0030 \pm 0.025$ \\
\hline & $\mathrm{CH}_{4}$ flux from $10 \mathrm{am} / \mathrm{mg} \cdot \mathrm{m}^{-2} \cdot \mathrm{h}^{-1}$ & -0.020 & 0.032 & 0.0074 & 0.010 \\
\hline & Mean $\mathrm{CO}_{2} / \mathrm{mg} \cdot \mathrm{m}^{-2} \cdot \mathrm{h}^{-1}$ & $237.78 \pm 340.43$ & $2.35 \pm 107.18$ & $50.12 \pm 46.35$ & $284.66 \pm 316.18$ \\
\hline & $\mathrm{CO}_{2}$ flux from $10 \mathrm{am} / \mathrm{mg} \cdot \mathrm{m}^{-2} \cdot \mathrm{h}^{-1}$ & 147.44 & -75.36 & 32.26 & 179.13 \\
\hline & Mean $\mathrm{NO}_{2} / \mu \mathrm{g} \cdot \mathrm{m}^{-2} \cdot \mathrm{h}^{-1}$ & $-3.67 \pm 16.72$ & $10.44 \pm 16.83$ & $11.25 \pm 20.89$ & $2.24 \pm 2.05$ \\
\hline & $\mathrm{NO}_{2}$ flux from $10 \mathrm{am} / \mathrm{mg} \cdot \mathrm{m}^{-2} \cdot \mathrm{h}^{-1}$ & -9.64 & 13.84 & 4.73 & 0.20 \\
\hline \multirow{3}{*}{ Dry lands } & $\mathrm{TDF} \mathrm{CH}_{4} / \mathrm{mg} \cdot \mathrm{m}^{-2} \cdot \mathrm{d}^{-1}$ & -0.37 & -0.44 & 0.61 & 0.0063 \\
\hline & $\mathrm{TDF} \mathrm{CO}_{2} / \mathrm{mg} \cdot \mathrm{m}^{-2} \cdot \mathrm{d}^{-1}$ & 9698.64 & 11423.34 & 3508.31 & 7007.41 \\
\hline & $\mathrm{TDF} \mathrm{NO}_{2} / \mu \mathrm{g} \cdot \mathrm{m}^{-2} \cdot \mathrm{d}^{-1}$ & 1271.77 & 1642.59 & 920.11 & 2897.10 \\
\hline \multirow{3}{*}{ Paddy field } & $\mathrm{TDF} \mathrm{CH}_{4} / \mathrm{mg} \cdot \mathrm{m}^{-2} \cdot \mathrm{d}^{-1}$ & 0.019 & 9.19 & 1.45 & -0.07 \\
\hline & $\mathrm{TDF} \mathrm{CO}_{2} / \mathrm{mg} \cdot \mathrm{m}^{-2} \cdot \mathrm{d}^{-1}$ & 5706.81 & 56.49 & 1202.96 & 6831.93 \\
\hline & $\mathrm{TDF} \mathrm{NO}_{2} / \mu \mathrm{g} \cdot \mathrm{m}^{-2} \cdot \mathrm{d}^{-1}$ & -88.19 & 250.64 & 269.97 & 53.88 \\
\hline
\end{tabular}




\section{Table 5 (on next page)}

Accumulative emission fluxes of $\mathrm{CH}_{4}, \mathrm{CO}_{2}$ and $\mathrm{N}_{2} \mathrm{O}$ and the Global Warming Potential of soil surface in Wuyang Bay over the growing season 
1

\begin{tabular}{|c|c|c|c|c|c|c|c|c|c|c|c|c|}
\hline \multirow[t]{2}{*}{ Land uses } & \multicolumn{2}{|c|}{$\begin{array}{l}\mathrm{CH}_{4} \text { fluxes } \\
\left(\mathrm{kg} \cdot \mathrm{hm}^{-2}\right)\end{array}$} & \multicolumn{2}{|c|}{$\begin{array}{l}\mathrm{CO}_{2} \text { fluxes } \\
\left(\mathrm{kg} \cdot \mathrm{hm}^{-2}\right)\end{array}$} & \multicolumn{2}{|c|}{$\begin{array}{l}\mathrm{N}_{2} \mathrm{O} \text { fluxes } \\
\left(\mathrm{kg} \cdot \mathrm{hm}^{-2}\right)\end{array}$} & \multicolumn{2}{|c|}{$\begin{array}{c}\mathrm{CH}_{4} \text { fluxes } \\
\text { equivalent } \\
\left(\mathrm{kg}\left(\mathrm{CO}_{2}\right) \cdot \mathrm{hm}^{-2}\right)\end{array}$} & \multicolumn{2}{|c|}{$\begin{array}{c}\mathrm{N}_{2} \mathrm{O} \text { fluxes } \\
\text { equivalent ( } \\
\left.\mathrm{kg}\left(\mathrm{CO}_{2}\right) \cdot \mathrm{hm}^{-2}\right)\end{array}$} & \multicolumn{2}{|c|}{$\begin{array}{c}\text { GWP } \\
\left(\mathrm{kg}\left(\mathrm{CO}_{2}\right) \cdot \mathrm{hm}^{-2}\right)\end{array}$} \\
\hline & 2015 & 2016 & 2015 & 2016 & 2015 & 2016 & 2015 & 2016 & 2015 & 2016 & 2015 & 2016 \\
\hline Paddy fields & 75.69 & 13.39 & 5619.74 & 10724.03 & 1.16 & 1.11 & 2119.20 & 374.84 & 306.52 & 293.18 & 8045.46 & 11392.06 \\
\hline Dry lands & 4.72 & 1.59 & 13694.61 & 11726.90 & 2.26 & 2.15 & 132.15 & 44.42 & 599.31 & 569.26 & 14426.07 & 12340.58 \\
\hline Grass fields & na & 2.95 & na & 17700.26 & na & 2.04 & na & 82.47 & na & 539.94 & na & 18322.66 \\
\hline
\end{tabular}

2 


\section{Table 6(on next page)}

Correlation matrix showing the relationship between RDA axes and significant $(P<$ 0.05 ) environmental variables, and the results of the RDA analysis.

In this figure, $\mathrm{TC}$ : soil total carbon; $\mathrm{NO}_{3}^{-}$: nitrate nitrogen; $\mathrm{ST}$ : soil temperature; VWC:soil volumetric water content; MWC:soil mass water content, AT: air temperature; DOC: dissolved organic carbon 


\begin{tabular}{|c|c|c|c|c|c|c|c|c|}
\hline \multirow[t]{2}{*}{ Axis Variable } & \multicolumn{2}{|c|}{ All data } & \multicolumn{2}{|c|}{ Dry lands } & \multicolumn{2}{|c|}{ Paddy fields } & \multicolumn{2}{|c|}{ Grass fields } \\
\hline & Axis 1 & Axis2 & Axis 1 & Axis2 & Axis 1 & Axis2 & Axis 1 & Axis2 \\
\hline Elevation & & & & & -0.831 & -0.557 & & \\
\hline Soil VWC & -0.997 & 0.080 & & & -0.999 & 0.036 & -0.896 & -0.444 \\
\hline Soil WC & -0.998 & -0.061 & 0.304 & 0.952 & -0.999 & 0.029 & & \\
\hline $\mathrm{AT}$ & 0.839 & 0.544 & 0.962 & 0.275 & 1.000 & -0.001 & & \\
\hline ST & 0.994 & -0.110 & & & 0.999 & 0.025 & & \\
\hline $\mathrm{NO}_{3}^{-}$ & 0.424 & 0.906 & 0.999 & -0.020 & & & & \\
\hline $\mathrm{TC}$ & -0.469 & -0.883 & & & & & & \\
\hline DOC & & & & & -0.999 & -0.031 & & \\
\hline Eigenvalues & 0.003 & 0.002 & 0.018 & 0.002 & 0.006 & 0.000 & 0.010 & 0.001 \\
\hline $\begin{array}{l}\text { Cumulative percentage variance of } \\
\text { species-environment relation }(\%)\end{array}$ & 25.23 & 37.30 & 48.73 & 53.96 & 45.51 & 45.56 & 24.74 & 26.18 \\
\hline
\end{tabular}

2

3 
Table 7 (on next page)

$\mathrm{CH}_{4}, \mathrm{CO}_{2}$ and $\mathrm{N}_{2} \mathrm{O}$ fluxes from different lands. 


\begin{tabular}{|c|c|c|c|c|c|}
\hline Location & Land type & $\begin{array}{l}\mathrm{CH}_{4} \quad \text { fluxes } \\
\left(\mathrm{mg} \cdot \mathrm{m}^{-2} \cdot \mathrm{h}^{-1}\right)\end{array}$ & $\begin{array}{l}\mathrm{CO}_{2} \text { fluxes } \\
\left(\mathrm{mg} \cdot \mathrm{m}^{-2} \cdot \mathrm{h}^{-1}\right)\end{array}$ & $\begin{array}{l}\mathrm{N}_{2} \mathrm{O} \text { fluxes } \\
\left(\mu \mathrm{g} \cdot \mathrm{m}^{-2} \cdot \mathrm{h}^{-1}\right)\end{array}$ & Ref. \\
\hline \multirow{3}{*}{ Yetang Creek,TGR,China } & corn fields & $-0.13 \sim 0.77$ & $85.09 \sim 420.78$ & $2.39 \sim 151.11$ & \multirow{3}{*}{ Current study } \\
\hline & paddy fields & $-0.0098 \sim 4.57$ & $-24.56 \sim 537.47$ & $-30.71 \sim 101.76$ & \\
\hline & fallow grasslands & $-0.017 \sim 0.36$ & $212.41 \sim 803.74$ & $0.94 \sim 117.61$ & \\
\hline Beijia Creek, TGR,China, & dike-ponds & $0.26-7.69$ & $171.24-275.72$ & $-30.0 \sim 100$ & Zhou et al., 2017 \\
\hline \multirow{2}{*}{ Lijiaba, TGR, China } & fallow grasslands & $-0.36 \sim 0.086$ & $124.96 \sim 865.92$ & $1.76 \sim 34.32$ & \multirow[t]{2}{*}{ Li et al., 2016} \\
\hline & corn fields & $-0.13 \sim 0.052$ & $321.64 \sim 599.72$ & $0.11 \sim 701.36$ & \\
\hline Miyun reservoir & riparian zone & $0.05 \sim 6.4$ & $-98 \sim 2274$ & $-136.6-381.8$ & Yang, 2016 \\
\hline $\begin{array}{l}\text { Carteret county, North } \\
\text { Carolina }\end{array}$ & marsh Wetland & $-0.22 \sim 0.31$ & $-166.62 \sim 323.3$ & $-70.0 \sim 75.36$ & Shiau et al., 2016 \\
\hline $\begin{array}{l}\text { Sanjiang Plain,Northern } \\
\text { China }\end{array}$ & marsh wetland & $-0.16 \sim 1.71$ & -- & $-1.24 \sim 4.65$ & Yu et al., 2010 \\
\hline Outer coastal plain, US & $\begin{array}{l}\text { restored } \\
\text { wetland }\end{array}$ & $-0.04 \sim 0.32$ & $91.38 \sim 740.24$ & $-6.28 \sim 792.85$ & Morse., 2012 \\
\hline Praire Pothole ,Canada & wetland & $0.21 \sim 2.22$ & -- & $2.20 \sim 3.27$ & Badiou et al., 2011 \\
\hline \multirow{2}{*}{ Glaciated plains,US } & cropland in wetland & $1.08 \sim 111.25$ & -- & $30.42 \sim 43.75$ & \multirow{2}{*}{ Tangen et al., 2015} \\
\hline & cropland upland & $0.0042 \sim 0.20$ & -- & $20.46 \sim 33.75$ & \\
\hline Croping system, US & corn fields & -- & $91.75 \sim 917.5$ & $-39.25 \sim 425.20$ & $\begin{array}{l}\text { ADVIENTO - BORBE MAA et } \\
\text { al., } 2007\end{array}$ \\
\hline Croping system, US & corn fields & $\begin{array}{l}0.0072 \sim 0.011 \\
7\end{array}$ & -- & $8.12 \sim 121.13$ & Amos et al., 2005 \\
\hline \multirow{3}{*}{$\begin{array}{l}\text { Freeman farm, US } \\
\text { SiChuan, croping system, } \\
\text { China }\end{array}$} & corn-soybean fileds & $-0.37 \sim 0.88$ & $1167.24 \sim 2806.7$ & $-170.23 \sim 448.74$ & \multirow{3}{*}{$\begin{array}{l}\text { Panday et al., } 2015 \\
\mathrm{Su}, 2016\end{array}$} \\
\hline & corn fields & $-0.11 \sim 3.95$ & $485.83 \sim 703.63$ & & \\
\hline & paddy fields & $0.00 \sim 17.8$ & $232.47 \sim 378.77$ & 19.64 & \\
\hline HuBei, cropping system & paddy fields & $4.39 \sim 15.6$ & & & Lin , 2000 \\
\hline SiChuan, cropping system & paddy fields & $1.66 \sim 17.51$ & & & Han, 2005 \\
\hline
\end{tabular}


Figure 1

Water level fluctuation of Three Gorges Reservior from 2015 to 2016

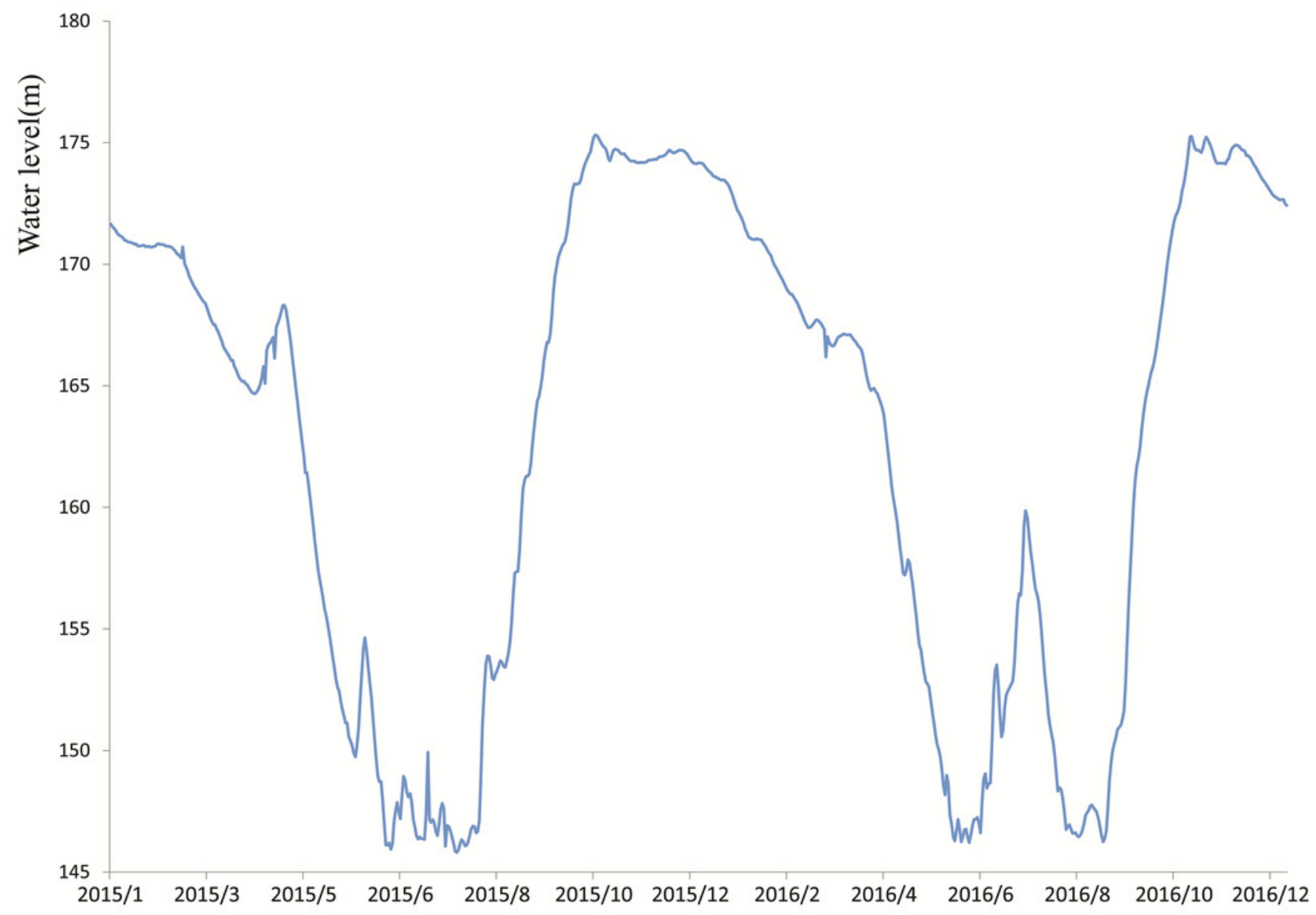


Figure 2

The location and land use status of Wuyang Bay

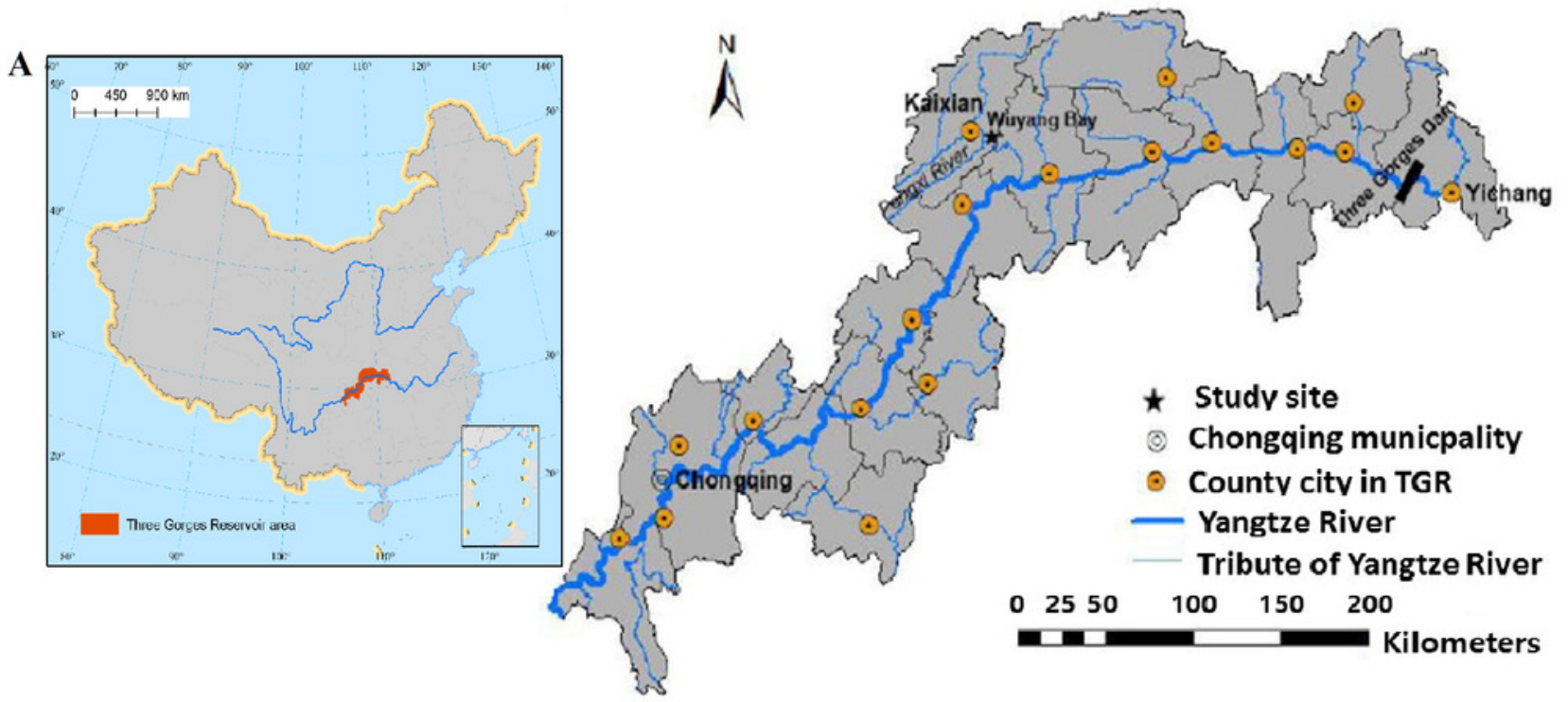

B
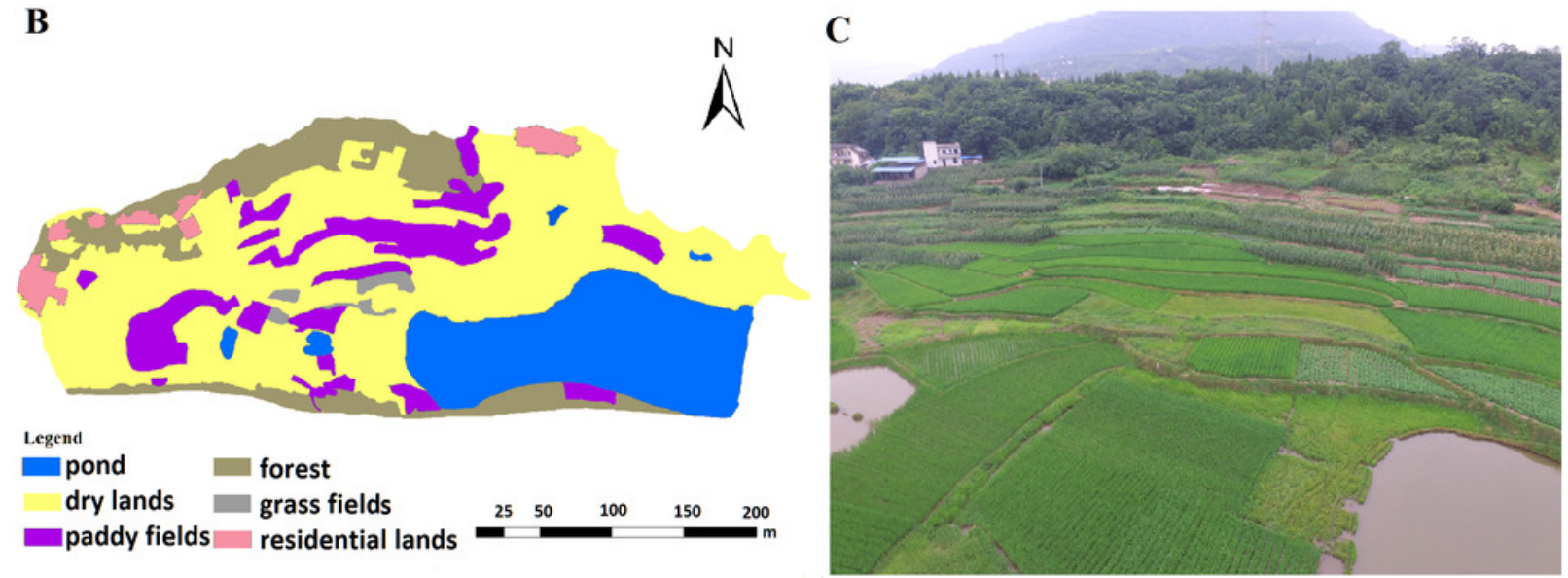
Figure 3

Diagram of sampling chamber used in this study

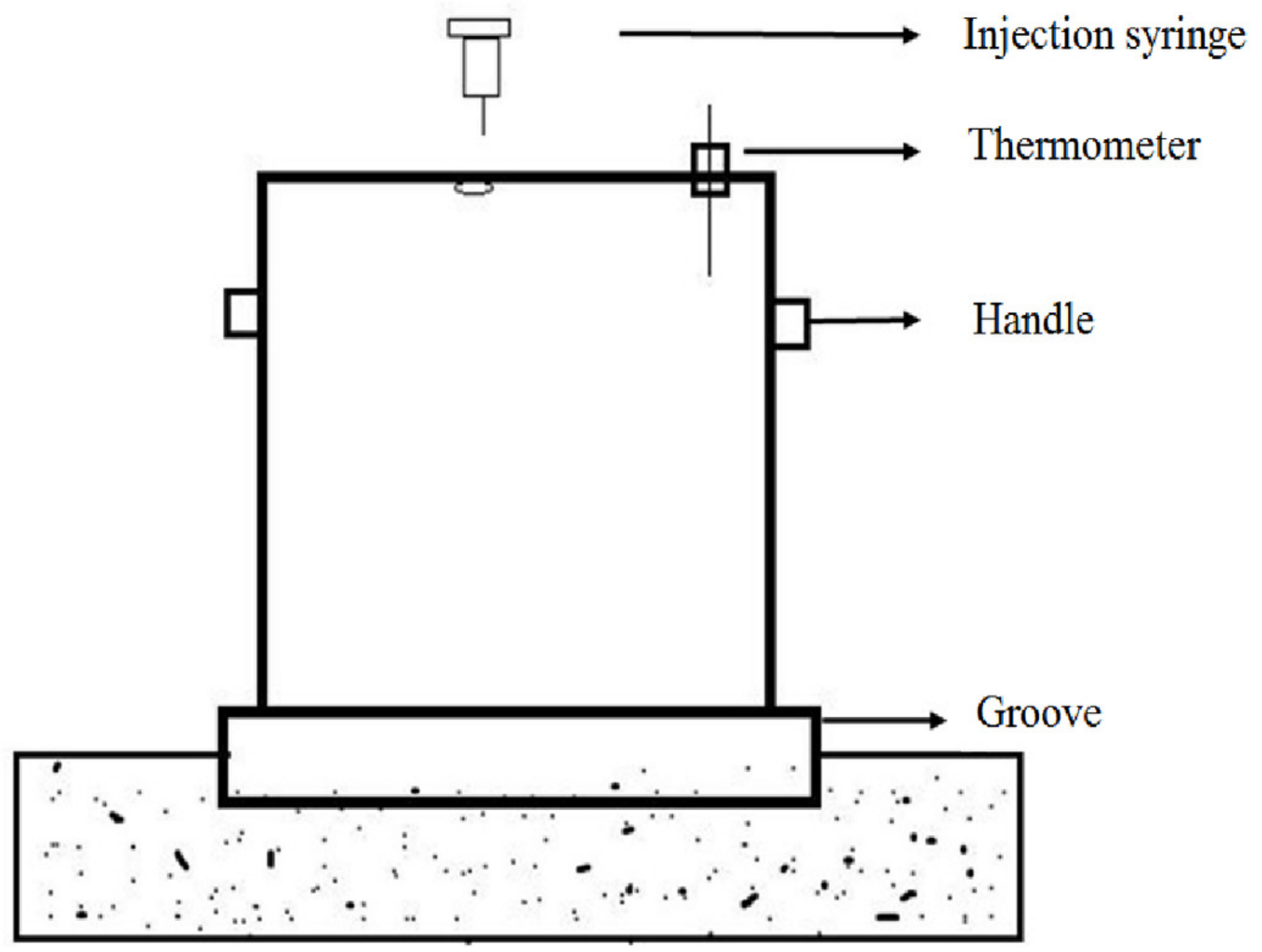


Figure 4

$\mathrm{CH}_{4}, \mathrm{CO}_{2}$ and $\mathrm{N}_{2} \mathrm{O}$ emissions of different elevations in Wuyang Bay in the growing season in 2015

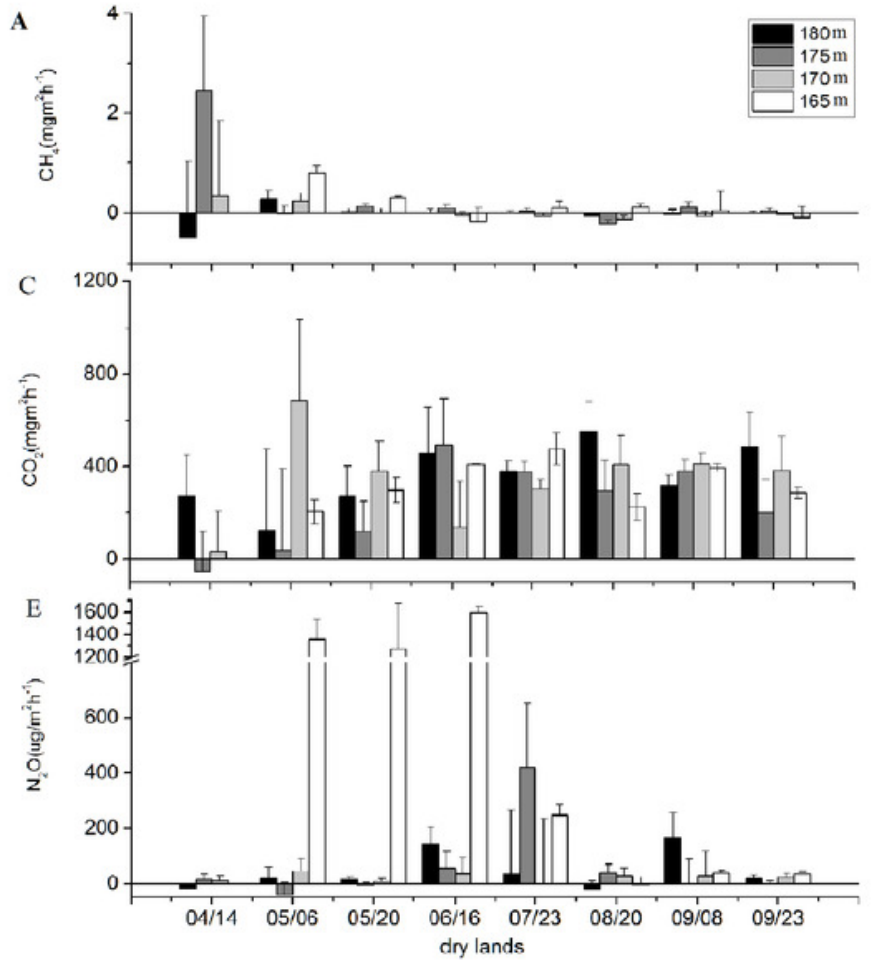

B

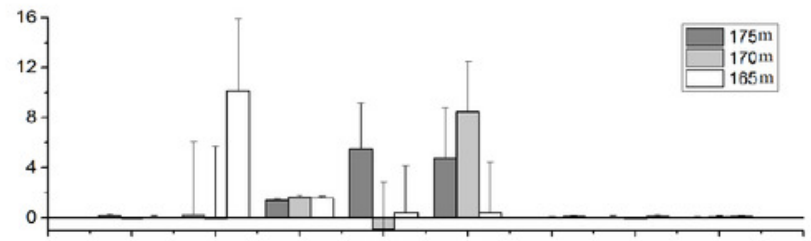

D 1200

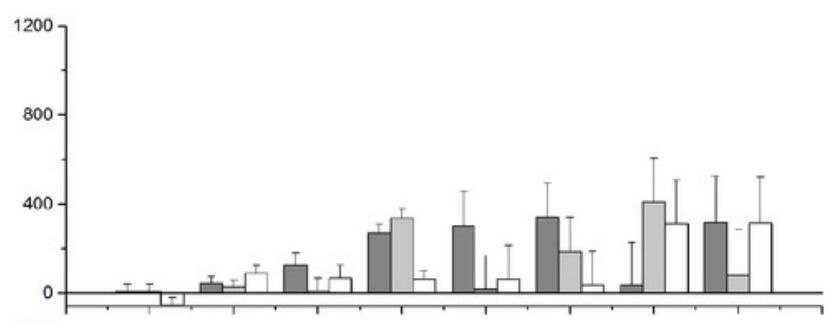

F 400

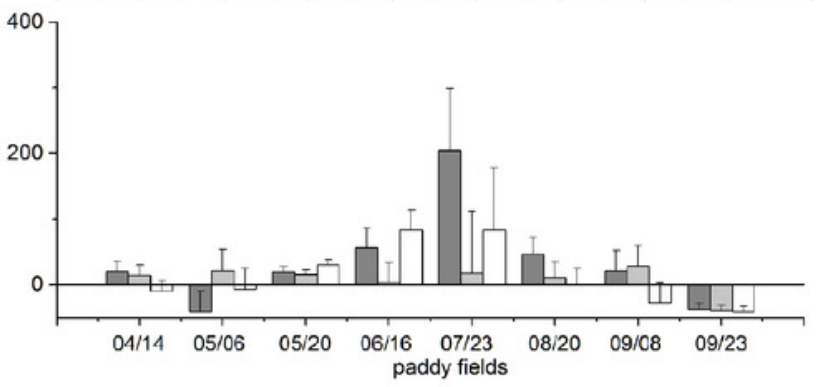


Figure 5

$\mathrm{CH}_{4}, \mathrm{CO}_{2}$ and $\mathrm{N}_{2} \mathrm{O}$ emissions from drylands, paddy fields and grass fields at the elevation of $170 \mathrm{~m}$ in the growing season in 2016
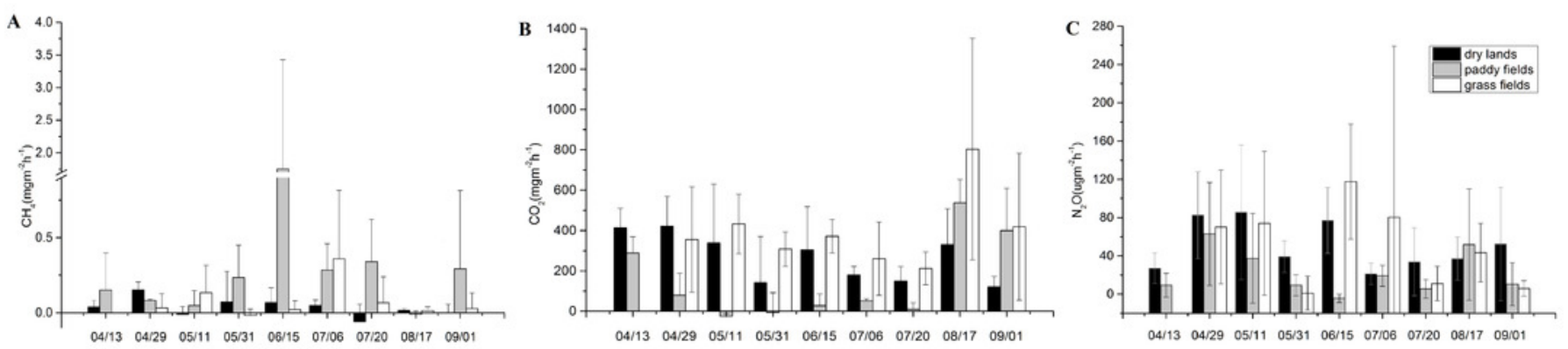
Figure 6

Diurnal emissions of $\mathrm{CH}_{4}, \mathrm{CO}_{2}$ and $\mathrm{N}_{2} \mathrm{O}$ in different seasons during the growing period
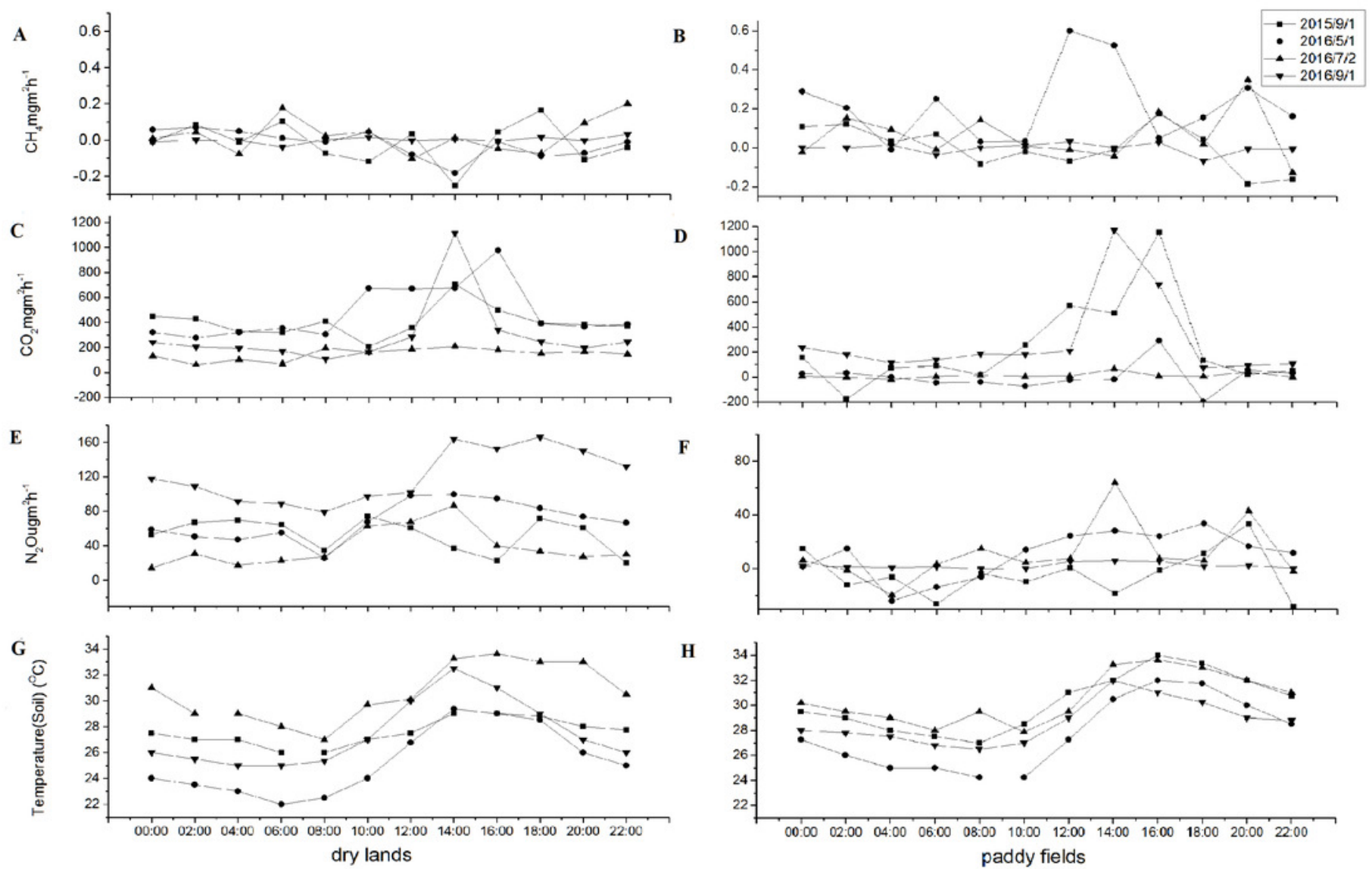

H

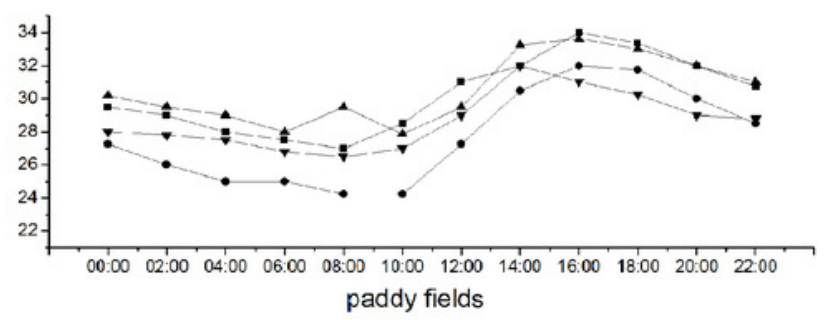




\section{Figure 7}

Redundancy analysis between $\mathrm{CH}_{4}, \mathrm{CO}_{2}$ and $\mathrm{N}_{2} \mathrm{O}$ emissions and environmental parameters

A)All data(2015-2016); B)paddy fields; C)uplands; D):grasslands (2016). Red arrows are GHG emissions, and blue arrows are environmental parameters. In this figure, TC: soil total carbon; $\mathrm{TN}$ : soil total nitrogen; $\mathrm{NO}_{3}$ : nitrate nitrogen; $\mathrm{NH}_{4}^{+}$: ammonia nitrogen;ST: soil temperature; VWC:soil volumetric water content; MWC:soil mass water content, AT: air temperature; DOC: dissolved organic carbon
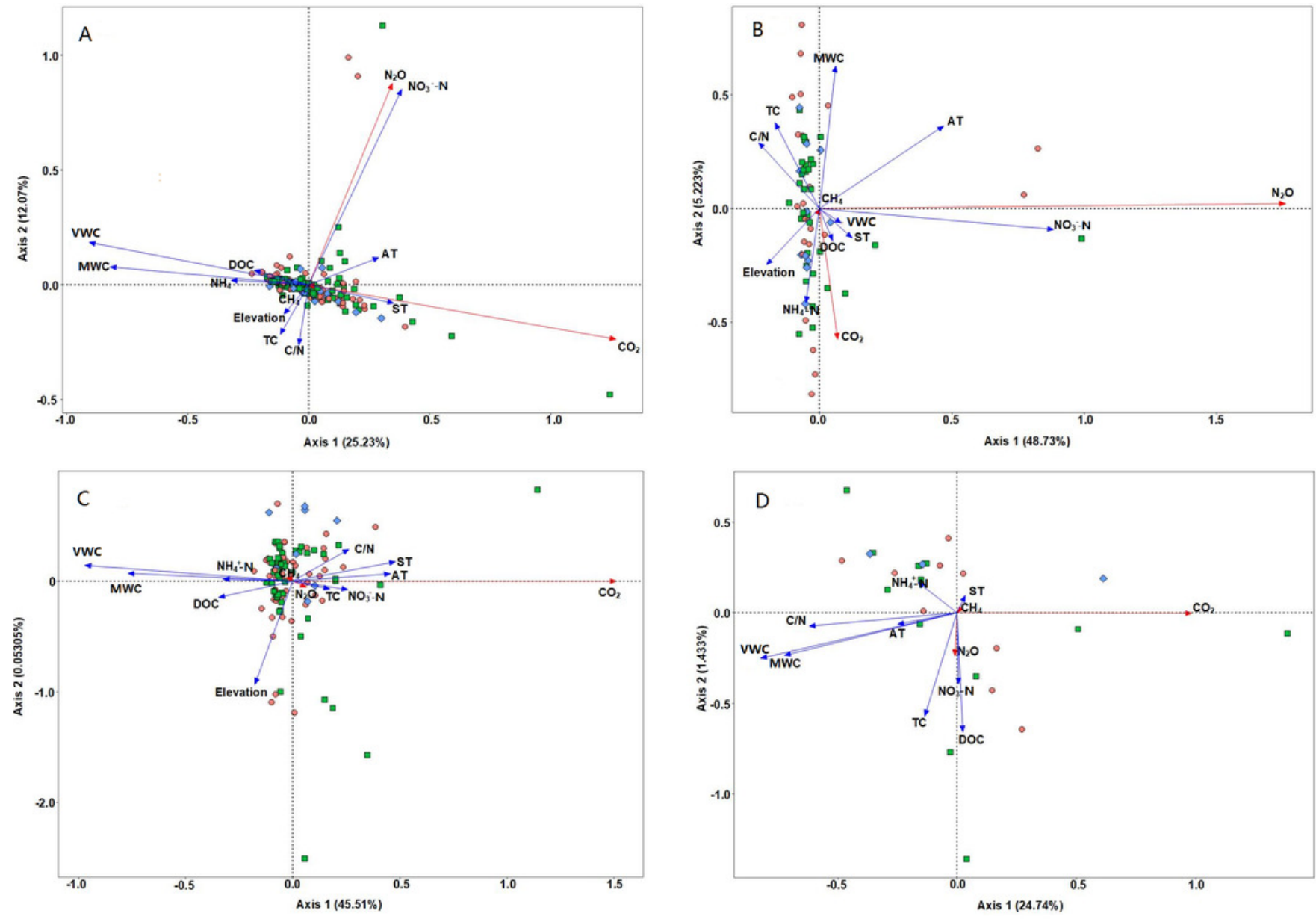

Spring $\square$ Summer $\diamond$ Autumn 